IZA DP No. 10264

Benefit Duration and Job Search Effort:

Evidence from a Natural Experiment

Andreas Lichter

October 2016 


\title{
Benefit Duration and Job Search Effort: Evidence from a Natural Experiment
}

\author{
Andreas Lichter \\ $I Z A$
}

\section{Discussion Paper No. 10264 \\ October 2016}

\author{
IZA \\ P.O. Box 7240 \\ 53072 Bonn \\ Germany \\ Phone: +49-228-3894-0 \\ Fax: +49-228-3894-180 \\ E-mail: iza@iza.org
}

\begin{abstract}
Any opinions expressed here are those of the author(s) and not those of IZA. Research published in this series may include views on policy, but the institute itself takes no institutional policy positions. The IZA research network is committed to the IZA Guiding Principles of Research Integrity.

The Institute for the Study of Labor (IZA) in Bonn is a local and virtual international research center and a place of communication between science, politics and business. IZA is an independent nonprofit organization supported by Deutsche Post Foundation. The center is associated with the University of Bonn and offers a stimulating research environment through its international network, workshops and conferences, data service, project support, research visits and doctoral program. IZA engages in (i) original and internationally competitive research in all fields of labor economics, (ii) development of policy concepts, and (iii) dissemination of research results and concepts to the interested public.
\end{abstract}

IZA Discussion Papers often represent preliminary work and are circulated to encourage discussion. Citation of such a paper should account for its provisional character. A revised version may be available directly from the author. 


\section{ABSTRACT}

\section{Benefit Duration and Job Search Effort: Evidence from a Natural Experiment ${ }^{*}$}

Findings of prolonged non-employment spells due to more generous unemployment benefits are commonly seen as an indication of reduced job search effort and moral hazard behavior. However, to date, there is hardly any direct evidence of benefit-induced reductions in search effort. This paper exploits quasi-experimental variation in the potential benefit duration in Germany paired with individual-level data on job search behavior to directly investigate this assumed relationship. The results of this study provide substantial support for strategic job search behavior in response to the generosity of the benefit scheme: the extension of the benefit duration caused job search effort to significantly decrease, lowering the number of filed applications and the probability of applying for a job that requires moving. In line with theory, it is shown that the reduction in search effort is accompanied by a significant decrease in the short-run job-finding rate. Instrumental variables estimates further provide causal evidence on the direct relationship between search effort and unemployment duration: a 10 percent increase in the number of filed job applications is found to increase the short-run job-finding probability by 1.3 percentage points.

JEL Classification: $\quad$ D83, I38, J64, J68

Keywords: $\quad$ job search, unemployment insurance, natural experiment, Germany

Corresponding author:

Andreas Lichter

IZA

P.O. Box 7240

53072 Bonn

Germany

E-mail: lichter@iza.org

\footnotetext{
* I would like to thank Patrick Arni, Pierre Cahuc, Stefano DellaVigna, Michael Krause, Max Löffler, Robert Mahlstedt, Ulrike Malmendier, Andreas Peichl, Gerard Pfann, Amelie Schiprowski, Sebastian Siegloch, Johannes Schmieder, Konstantinos Tatsiramos, Josef Zweimüller as well as seminar and conference participants at IZA Bonn, ZEW Mannheim, SOLE 2016, NBER TAPES 2016, EALE 2016, and the University of Mannheim for many valuable comments and suggestions. The author is further grateful to the data services of the IDSC of IZA.
} 


\section{Introduction}

A central challenge of unemployment insurance (UI) schemes is enabling unemployed individuals to actively search for suitable re-employment opportunities by partly compensating for income losses while at the same time repressing the unintended incentives to lower search intensity. However, disincentive effects of UI systems, triggered by both the level of benefits as well as the potential benefit duration (PBD), have been well identified by empirical research. Put briefly, extensions of the PBD have been shown to significantly extend individuals' non-employment duration, irrespective of personal characteristics or institutional regulations of the labor market (see, for example, Katz and Meyer, 1990; Card and Levine, 2000; Lalive et al., 2006, Van Ours and Vodopivec, 2006; Chetty, 2008; Schmieder et al., 2012. 2016) ${ }^{1}$

While standard job search theory predicts that increases in the duration of non-employment spells due to the extension of the PBD can be attributed to lower search effort and/or higher reservation wages, direct empirical evidence regarding the importance of reduced job search effort in contributing to this aggregate effect is sparse. Instead, findings of prolonged spells of non-employment are rather commonly interpreted as suggestive evidence of reduced search effort and the presence of moral hazard, although Chetty (2008) shows that liquidity effects must also be accounted for. To date, only two contemporaneous studies by Marinescu (2015) and Baker and Fradkin (2016), both focusing on Internet job search at the aggregate U.S. state level, provide direct empirical albeit mixed evidence of the proposed mechanism $2^{2}$

The present paper adds to this scarce evidence by using quasi-experimental variation in the $\mathrm{PBD}$ for one specific age group of the unemployed in conjunction

\footnotetext{
1 Card et al. (2007) show that the extent of the observed spike in exit rates prior to the expiration of benefits significantly depends on the measurement of individuals' unemployment spells: re-employment hazards increase significantly less than unemployment exit rates. Given that unemployment registration is not mandatory in many countries after benefit exhaustion, spikes in unemployment exit rates may hence overstate the extent of an UI-induced moral hazard.

${ }^{2}$ Using data from a large online job board and U.S. state-level variation in the PBD, Marinescu (2015) shows that extensions of the PBD led to a substantial decline in the aggregate number of applications. In turn, Baker and Fradkin (2016) use Google Trends data to measure aggregate job search effort. Following the event study approach of Marinescu (2015), their findings suggest no meaningful decreases in aggregate job search effort in response to extensions of the PBD.
} 
with detailed, direct information on individuals' total job search effort (online and offline) and reservation wage choices to provide causal evidence of the effect of the benefit duration on job search behavior and the associated job-finding rates. Variation in the PBD comes from an unexpected and rapidly-implemented policy change in Germany in late 2007. The new legislation was motivated by concerns of social injustice and took place during times of stable macro-economic conditions. On November 13, 2007, only six weeks after the initial reform proposal, the then-acting coalition of the Christian Democrats (CDU) and Social Democrats (SPD) decided upon and announced the extension of the PBD for eligible workers aged 50 to 54 by twelve weeks (from twelve to fifteen months), while the PBD for younger workers remained unaffected. The corresponding law was passed by parliament on January 28, 2008 and retroactively imposed to January 1, 2008 ? $^{3}$

Using data from the IZA Evaluation Dataset Survey, which covers a large sample of individuals registering as unemployed at the German Federal Employment Agency between June 2007 and May 2008, I exploit this policy reform to investigate the effects of the PBD on individuals' short-run job search behavior and job-finding probabilities. Unemployed workers aged 45 to 49 , who were not affected by the reform, are taken as a control group, which enables applying simple difference-in-differences techniques. Importantly, the swiftness of the political process and uncertainty about the design of the reform until its public announcement on November 13, 2007 limit the scope of adaptive behavior. The reform's detachedness from economic conditions further confines the extent of endogenous policy bias.

The results of this study show that job seekers significantly reduced their search effort in response to the extension of the PBD. Individuals entitled to an additional twelve weeks of unemployment benefits filed fewer job applications and were less likely to apply for jobs in distant areas. For example, the number of filed applications decreased by around 1.8 applications per week on average, with the effects proving robust to the inclusion of a variety of personal and regional control

\footnotetext{
${ }^{3}$ As detailed below, workers were subject to the reform in case of having contributed to UI for at least twelve months within the last two years (eligibility constraint) and for 30 months within the last five years. Note that the reform also extended the PBD for eligible workers aged 58 and above. However, given that this study bases on data covering unemployed individuals aged 16 to 54 only, the effects of this change are not investigated.
} 
variables. In contrast, the increase in the PBD had no effect on reservation wages, which is counterintuitive to theory but in line with recent evidence demonstrating the limited responsiveness of reservation wages with respect to changes in UI parameters Krueger and Mueller, 2016; Schmieder et al., 2016). Relying on the rich information in the dataset, the analysis further suggests that the observed reductions in job search effort can be attributed to moral hazard behavior as treated individuals seem to suspend their job search in light of the extended benefit duration. Changes in job search effort are further found to be substantially smaller in areas with high unemployment, i.e. in labor markets where reductions in search effort appear to be costlier.

In line with the theoretical predictions of standard job search models, I further show that the UI-induced reduction in search effort is accompanied by a significant decrease in the short-run job-finding rate. Reduced form estimates show that the probability of exiting to employment significantly decreases in response to the reform, in particular for individuals who had been subject to unemployment prior to the current spell. Instrumental variables estimates, which explicitly account for the endogeneity of individuals' job search behavior by instrumenting search effort with the reform's induced variation in the PBD, further provide causal direct evidence of the effect of job search effort on job-finding rates. Evaluated at the mean, a ten percent increase in the number of filed applications is found to raise short-run jobfinding rate by around 1.3 percentage points. However, the underlying relationship seems to be non-linear in nature, given that returns to search effort are positive but diminishing.

Overall, the present study offers considerable evidence of strategic job search behavior in response to the generosity of the benefit scheme. The observed reductions in individuals' job search effort following the extension of the PBD thus correspond and add to the aggregate evidence provided by Marinescu (2015) for the United States. In line with job search theory, the present study also demonstrates that these UI-induced reductions in job search effort significantly lower individuals' job-finding rates. Instrumental variables estimates establish the causal link between search effort and job-finding rates, which has - to the best of my knowledge - not 
been empirically tested before. Most related to this finding is recent work by Arni and Schiprowski (2015), who show that changes in job search effort due to externallyimposed requirements increase job-finding rates but do not provide direct estimates of the elasticity of job-finding with respect to job search effort.

The paper proceeds as follows. Section 2 offers a brief overview of the institutional characteristics of the German labor market and highlights the key features of the reform of interest. Information on the dataset is presented in Section 3, Section 4 provides the empirical model and details the underlying identification strategy. The results of this analysis are presented in Sections 5, before Section 6 concludes.

\section{The institutional setting}

In Germany, all employees subject to social security contributions are covered by UI and entitled to receive unemployment benefits if they had contributed to the insurance scheme for at least twelve months within the last two years preceding their job loss. The duration of benefits is subject to the number of months employed within a given time frame and discontinuously increases with age. $4^{4}$ Monthly benefits amount to $60 \%$ ( $67 \%$ for recipients with children) of the last net wage, which is capped at the upper ceiling of the social security contributions. Payments are generally rescinded for up to twelve weeks if workers terminate their job themselves, which lowers the maximum benefit duration accordingly. Each recipient of unemployment benefits is further obliged to actively search for a job and to be at the Employment Service's disposal, while failure to comply with these requirements may result in benefit cuts.5 Individuals who are not entitled for or exhaust their unemployment benefits may receive welfare benefits, which are granted for an unlimited period and designed to assure living at the subsistence level.

The 2007 reform of the UI scheme The extension of the PBD for older workers in late 2007 was the result of an unexpected policy reform under the grand coalition of Christian Democrats (CDU) and Social Democrats (SPD). As highlighted below,

\footnotetext{
${ }^{4}$ See Table A.1 in the Appendix for details on the institutional setting prior to/after the reform.

${ }^{5}$ Note that there is no general minimum number of applications required by law.
} 
the remarkably rapid implementation of the reform proposal and uncertainty about the design of the reform until its public announcement substantially limit the scope of avoidance behavior. The reform's detachedness from business cycle conditions further significantly confines the extent of endogenous policy bias. In the following, I detail the key features of this reform.

Since their implementation in the early 2000s, the Social Democrats were heavily divided about the evaluation of their large, structural reforms that had made the German labor market much more flexible (Hartz IV, Agenda 2010, among others) but had constituted a significant shift in the party's policy agenda, resulting in electoral defeats and a challenge to the identity of the party. On October 1, 2007, the then-acting party leader of the Social Democrats, Kurt Beck, marked the party's public turn from its (more) liberal policy by calling for an extension of the PBD for older workers. The reform proposal was motivated on the grounds of social injustice concerns - long periods of UI contributions were ought to be rewarded by extended $\mathrm{PBD}^{6}$ - and was made during times of stable macro-economic conditions (see Figure A.1 in the Appendix).

The initial proposal was met with considerable skepticism, from politicians in both the Christian Democratic and the Social Democratic parties. Disagreement about the proposal, and hence uncertainty about the implementation of the suggested reform, lasted for several weeks and prompted rumors about the collapse of the acting coalition. To ease the growing tensions? both parties negotiated over pending disputes in a coalition meeting on the night of November 12 , and a general decision in favor of an extension of the PBD "at the earliest possible time" 8 as well as about the actual changes in the UI scheme was announced by the following morning.

While the then Minister of Employment, Franz Münterfering (SPD), resigned

6 The reform proposal followed claims of the German Trade Union Confederation (DGB), who initially suggested the extension of the PBD for all workers aged 45 and above to up to 24 months.

7 The coalition also disagreed about other pending topics, such as the introduction of minimum wages in the postal sector, for example.

8 Volker Kauder, faction leader of the CDU/CSU, as quoted in "Spiegel Online" on November 13, 2007 (http://www.spiegel.de/politik/deutschland/einigung-bei-arbeitslosengeld-beitrag-sinktauf-3-3-prozent-laenger-geld-fuer-aeltere-a-516982.html, last assessed in August 2016). 
over this decision? the coalition rapidly implemented the legislative process. On December 11, 2007, the corresponding law was issued to parliament. The reform was eventually passed by parliament on January 26, 2008 and retroactively implemented to January 1, 2008. As in previous reforms, the new law contained a transitional agreement, which extended the PBD for those job seekers who were unemployed prior to the reform, fulfilled the set entitlement criteria and whose eligibility period was not exhausted by December 31, 2007 ${ }^{10}$

Ultimately, the reform affected those unemployed individuals aged 50 or above who fulfilled the set entitlement criteria. PBD for workers aged 50 to 54 was extended by twelve weeks (from twelve to fifteen months) if they had contributed to UI for at least twelve months within the last two years (eligibility constraint) and for 30 months within the last five years ${ }^{11}$ Likewise, UI benefit duration was extended from 18 to 24 months for all workers aged 58 or above if they had fulfilled the eligibility constraint and had contributed to UI for at least four out of the last five years. Table A.1 in the Appendix outlines the relationship between the claimant's age, the length of UI contributions and the PBD prior to (upper panel) and after the reform (lower panel). However, as the data used in this analysis focuses on unemployed individuals aged 16 to 54, this study only exploits information about the reform for the younger of the two age groups.

Public awareness about the reform The substantial public dispute across and within the two ruling parties as well as the surprising agreement about the reform after the nightly coalition meeting on November 12, 2007 caught great media attention throughout Germany, whereby it seems likely that a large part of the German society became aware of the adopted measures. Using Google Trends data, I show that individuals indeed noticed the particular reform of the UI scheme. As displayed in

\footnotetext{
9 Being a critic of this reform from the very beginning, he officially resigned due to private reasons on November 13, 2007.

10 Hence, the reform subsequently extended the PBD for all eligible individuals who had become unemployed before January 1, 2008 and were entitled to receive benefit payments on December 31, 2007 by three months (see $\S 434$ r, SGB III). Note that this only applied to those individuals who fulfilled both criteria (above the respective age threshold and sufficient contributions to UI) at the time of unemployment registration.

11 Note that the reform also extended the qualifying period from three to five years.
} 
Figure 1, search volume for the term "Arbeitslosengeld I" (unemployment benefits) over the period from July 2007 to July 2008 peaked exactly during the week of the reform's announcement (corresponding to November 11-17, 2007) and remained at a relatively high level until shortly after the passing of the law on January 28, 2008. By contrast, search volume for the term "arbeitslos" (being unemployed) remained remarkably constant over the period of interest, suggesting that the observed peak was indeed driven by individuals searching for information about (changes in) the UI scheme rather than general advice in case of unemployment.

Figure 1: Exploring the public awareness about the reform

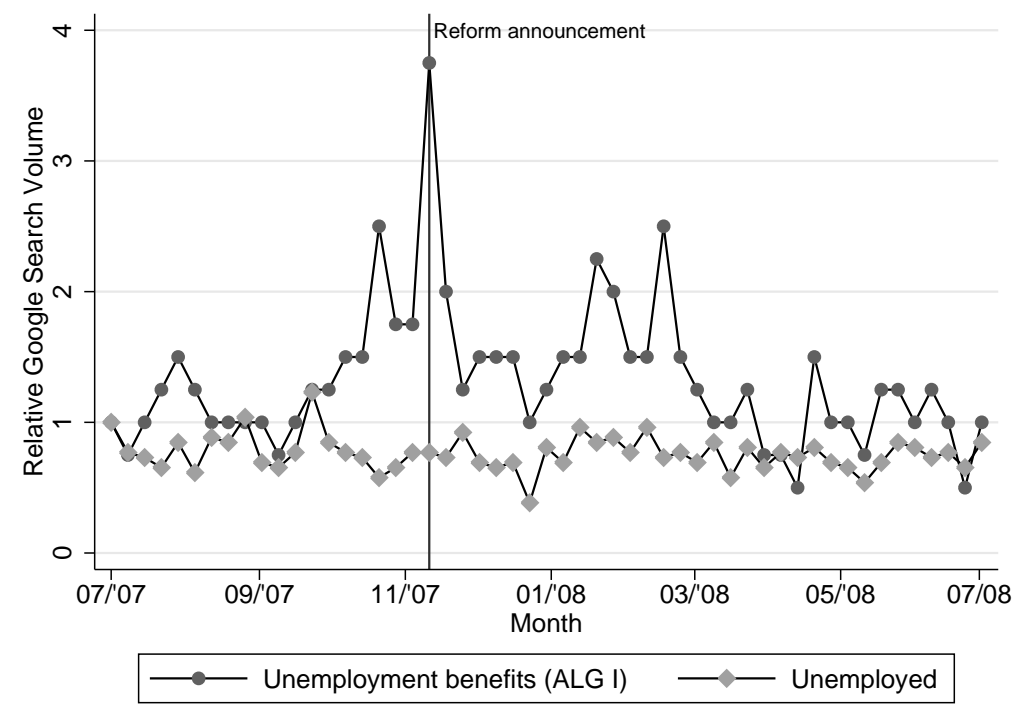

Notes: This figure presents the weekly Google search volume for the two terms "Arbeitslosengeld I" (unemployment benefits) and "arbeitslos" (unemployed). Note that Google does not provide absolute numbers but normalizes queries to allow observing relative changes in search intensities for one term over time. In order to ease the interpretation of this graph, I follow Garthwaite et al. (2014) and divide the given weekly numbers by the respective value for the first observation in this graph, corresponding to the week of July 1-7, 2007.

\section{Data}

In order to investigate the consequences of this reform, I use data from the IZA Evaluation Dataset Survey, which covers a large sample of individuals registering as unemployed at the German Federal Employment Agency between June 2007 and May 2008, i.e. prior to and after the reform (see Arni et al. (2014) for details). Designed to allow investigating active labor market program (ALMP) effects, the 
dataset surveys prime-aged workers (aged 16 to 54) who enter unemployment, search for re-employment opportunities and qualify for participation in ALMPs. In turn, individuals close to (early) retirement and all recipients of welfare benefits, who are thus not entitled for participation in ALMPs, are not covered by the survey.

In order to obtain a representative sample of the unemployed population and to account for seasonal effects over one year, the dataset is based on monthly random samples from the unemployment inflow statistics of the German Federal Employment Agency between June 2007 and May 2008. Overall, 17,396 individuals were first interviewed around two months after becoming unemployed and were repeatedly questioned over time. For the present analysis, the first wave of the survey is exploited, which provides detailed information on individuals' search behavior and job finding at the beginning of the unemployment spell. Among others, the survey covers information on the number of applications, the filing of applications that require moving and the reservation wage, i.e. the indicated lowest wage rate at which an unemployed person would consider working. This information is supplemented by a large set of variables on the respondents' employment history, personal characteristics (e.g. the age, education or level of professional training) and personality traits, such as the locus of control or the Big Five. The data also include information on individuals' supervision intensity by the local Employment Agencies (the number of agency visits or received job offers, among others) and local labor market conditions, such as regional unemployment and vacancy rates. Descriptive statistics for all outcome and control variables used in this study are provided in Appendix Table A.2 12

\section{Identification}

The present dataset thus allows me to observe the job search behavior and jobfinding rates of unemployed individuals who were interviewed prior to or after the

\footnotetext{
${ }^{12}$ In the analysis, I drop respondents who report implausibly high numbers of filed applications (more than 120), which corresponds to $0.7 \%$ of the sample $(\mathrm{N}=6)$. Note that the estimates remain qualitatively unaffected when revoking this condition.
} 
public announcement of the reform on November 13, 2007 13 Variation in the date of unemployment registration, the policy reform and the date of the interview provide a clear quasi-experimental setting to identify the effects of the PBD on job search effort and the associated job-finding probability.

Figure 2: Unemployment entry, survey date and expected benefit duration

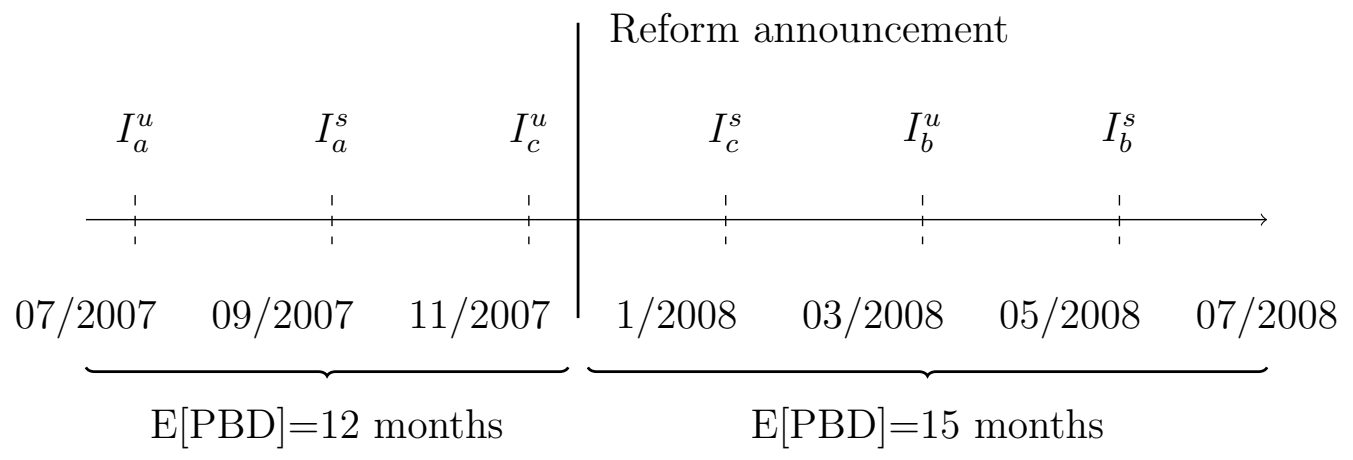

Notes: The figure plots the setting of this analysis. Individuals $I_{i} \forall_{i}=\{a, b, c\}$ registered as unemployed at $I_{i}^{u}$ and were surveyed/interviewed at $I_{i}^{s}$. Expectations about the potential benefit duration change on November 13, 2007, the day when the reform was agreed upon and announced to the public.

Figure 2 illustrates the setting of the analysis. Individual $I_{a}$ registered as unemployed $\left(I_{a}^{u}\right)$ and was surveyed about her job search behavior $\left(I_{a}^{s}\right)$ prior to the reform, thus choosing her job search effort while expecting a PBD of twelve months. In turn, individual $I_{b}$ became unemployed and chose job search effort while knowing about the extension of the PBD. For individual $I_{c}$, expectations about the PBD were updated after unemployment registration but prior to the interview. Some part of the relevant job search period was thus subject to the new PBD regime, whereas initial job search effort was chosen while expecting a PBD of twelve months. The job search effort of individual $I_{c}$ may thus have converged towards the effort level of individual $I_{b}$ after the extension of the PBD became public. In the empirical analysis presented below, special attention is paid to those individuals whose expectations about the PBD updated after unemployment registration but prior to the interview.

Based on this setting and in line with the empirical strategies pursued by

13 Although not all details about the reform were set before December 11, 2007, it seems likely that the announcement of the reform on November 13, 2007 already induced significant behavioral changes in individuals' job search effort. Job seekers seemed to be well aware that this type of policy change usually contains a transitional agreement and would thus also retroactively apply for then-unemployed individuals (for example, as indicated by discussions in relevant internet forums for unemployed persons). 
Kyyrä and Ollikainen (2008) as well as Van Ours and Vodopivec (2008), a simple difference-in-differences strategy is applied to compare pre- and post-reform outcomes. Unemployed workers aged 50 to 54 who were interviewed after the announcement of the reform and hence gained knowledge about the extension of the PBD prior to choosing (parts of) their job search behavior constitute the treatment group. Same-aged individuals interviewed prior to the introduction of the reform serve as the comparison group, which is the equivalent to the treatment group observations measured pre-treatment. Unemployed workers aged 45 to 49 interviewed prior to or after the reform serve as control groups to account for any seasonal aggregate effects.

Eligible individuals As highlighted before, benefit duration in Germany is subject to the claimant's age and length of UI contributions within a given qualifying period. The reform of interest thus only changed the PBD for a subset of individuals aged 50 to 54. Individuals were entitled to extended PBD if they had contributed to UI for at least twelve months within the last two years (eligibility constraint) and for 30 months within the last five years (coverage constraint). For the purpose of this analysis, all unemployed individuals who did not fulfill the contribution criteria were thus excluded, irrespective of the claimant's age. Unfortunately, the present dataset only provides information on the respondents' last employment period, which limits the analysis to those claimants who fulfilled both entitlement criteria without any interrupting period of non-employment. Compared to the entire eligible population, the individuals in this sample are thus positively selected regarding their labor market history, given that the sampled individuals were not subject to unemployment in their recent past. If the sampled individuals responded differently with respect to this reform compared to the eligible individuals not covered in the analysis, the estimates of this study may thus not provide the true treatment effect for the entire eligible population.

In general, heterogeneous responses by these two groups may be due to consequences and causes of prior unemployment experience. First, UI-induced changes in job search effort may be less (more) pronounced among the group of those eligible individuals who have experienced unemployment shortly before the current 
spell if these individuals had encountered net (dis)utility from unemployment and include past experiences in their current decision about job search effort. Second, unobservable and observable differences between both groups may have caused prior unemployment spells and could affect individuals' responses with respect to the reform of the PBD.

The results of my empirical analysis, however, suggest that past unemployment experience does not affect current choices of job search effort. As shown in Appendix Tables A.9 A.10, UI-induced reductions in job search effort are similar for individuals with and without previous spells of unemployment. Evidence in favor of more pronounced effects for the low- and medium-skilled compared to the high-skilled unemployed regarding (changes in) the probability of applying for a distant job further implies that the sample may underestimate the overall treatment effect for the entire eligible population if the covered sample is positively selected on (observed) skills ${ }^{14}$

Empirical model The present setting allows me to directly test the hypotheses of standard job search models. Using difference-in-differences techniques, it is tested whether an extension of the PBD lowers individuals' job search effort, increases their reservation wages and thus causes job-finding rates to decrease. The underlying empirical specification reads as follows:

$$
Y_{i}=\alpha+\beta T_{i}+\gamma A_{i}+\delta\left(T_{i} \times A_{i}\right)+X_{i}^{\prime} \rho+\varepsilon_{i}
$$

where the dependent variable $Y_{i}$ indicates measures of job search effort, the reservation wage or exit to employment of individual $i$. Term $T_{i}$ is a dummy variable indicating whether the individual was interviewed after the reform, term $A_{i}$ designates whether the individual is aged between 50 to 54 . The treatment effect is given by $\delta, X_{i}^{\prime}$ defines a vector of control variables and $\varepsilon_{i}$ the error term.

Identification of the model rests upon the standard assumptions that (i) no observable or unobservable individual characteristics determined the allocation to

\footnotetext{
14 Note that estimated treatment effects do not significantly differ by skills when focusing on the number of applications.
} 
the treatment or comparison group, and (ii) potential changes in labor market conditions over the sampling period affected treatment and control groups to an equal extent. Put more precisely, aside from differences in knowledge about the reform due to the timing of being interviewed/becoming unemployed, the comparison group should thus be highly similar to the treatment group. Moreover, changes in business cycle conditions should not have had asymmetric effects on treatment and control groups. The remainder of this section aims to validate these identifying assumptions.

Voluntary quits and strategic layoffs In order for the identifying assumptions to hold, layoffs have to be exogenous from the individuals' perspective. As some workers may, however, potentially opt to become unemployed in response to the extension of the PBD, the treatment group may be self-selected in this respect. To account for potential selection, all workers who voluntarily quit their job or became unemployed by mutual agreement are thus excluded from the sample ${ }^{15}$

Strategic layoff decisions by firms may further violate the identifying assumption. If firms deliberately suspend dismissals of older workers (aged 50 or above) to allow for a longer PBD, allocation into the treatment and comparison group would be non-random. Due to the fast implementation of the reform, adaptive behavior of firms is highly unlikely, and strict dismissal laws impede strategic timing of layoffs in Germany. However, as a robustness check, the analysis is further limited to layoffs where strategic timing of terminations can be ruled out, focusing on those workers who became unemployed due to plant closings, the expiration of a temporary contact and the like. As detailed below, the results of the analysis remain unaffected in the cases where the analysis is limited to the respective sub-groups.

Concurrent ALMP reforms Estimates would be also biased if simultaneous reforms had occurred that asymmetrically affected the treatment, comparison and control groups. Concurrent with the extension of the PBD, the government indeed introduced labor market integration vouchers (Eingliederungsgutscheine). In brief, these vouchers slightly modified eligibility criteria for unemployed individu-

${ }^{15}$ Excluding these individuals from the analysis further accounts for the fact that benefit payments can be suspended for up to twelve weeks if workers voluntarily opt out of employment, which lowers the PBD accordingly. 
als aged 50 or above so that they could receive employment integration subsidies (Eingliederungszuschüsse). These subsidies have long been used as an ALMP instrument in Germany, and all unemployed individuals are allowed to file for integration subsidies in general. Approval, duration and amount of the subsidy are subject to the discretion of the local Employment Agency and dependent upon applicants' work productivity limitations, with the scope and availability of integration subsidies being extended for individuals aged 50 or above (since May 2007).

The existence of integration vouchers and extended subsidies for the unemployed aged 50 or above should, however, not impede the causal interpretation of the findings in my analysis. Given that all unemployed individuals in the treatment and the comparison group were potentially eligible for extended subsidies in general, potential effects arising from these subsidies should be captured by the parameter of the age group dummy and thus should not affect the treatment effect of interest. Moreover, the slight modifications in the eligibility criteria for subsidies invoked by the introduction of the integration voucher as of January 1, 2008 only had a marginal, negligible effect on take-up rates. In 2008, the Federal Employment Agency granted 3,000 vouchers only, compared to more than 1.5 million ALMP measures in total (Statistics of the Federal Employment Agency) ${ }^{16}$

Observable characteristics by age group and interview period As highlighted above, besides differences in knowledge about the reform and the timing of becoming unemployed, the comparison and treatment group should be highly similar in observable characteristics. Moreover, labor market conditions should be either constant over time or change to an equal extent for the treatment and control group. The IZA Evaluation dataset allows for extensive testing of both identifying assumptions. Table 1 shows (differences in) mean characteristics by age groups and within the treatment and control group prior to and after the reform.

Columns (1) to (3) show means for the two age groups and the results of a simple t-test (p-values) on the equality of the means for a large set of variables.

\footnotetext{
${ }^{16}$ By April 2012, the voucher program was stopped. Over the course of its existence, a total of around 20,000 vouchers had been issued. The total number of subsidies granted was quite constant over the period of interest. Figure A.2 in the Appendix shows the annual number of integration subsidies from 2006 to 2010 .
} 
Besides expected differences in age, it becomes apparent that the two groups of individuals do not systematically differ. On average, individuals from both groups are married, had completed an apprenticeship and generated a monthly net labor income of around 1,400 euros prior to unemployment, for example ${ }^{17}$ Evaluated at the mean, both groups of workers further come from comparable regions across Germany, with differences in local unemployment rates being small and insignificant. Moreover, the individuals in both groups received similar supervision by local employment agencies; for example, by means of the number of agency visits or job offers. Finally, both groups are similar with respect to personality traits, measured by means of individuals' internal and external locus of control index (as defined in Caliendo et al. (2015)).

I further test whether mean characteristics within one age group differ before and after the reform. Columns (4) to (9) show the corresponding results. Both of the control groups as well as the comparison and treatment group are highly similar in terms of observable personal characteristics. Most importantly, the treatment and control group neither differ in terms of personal characteristics nor personality traits when being compared pre- and post-treatment. The only exception concerns the level of occupational training, which is lower in both the control and treatment group after the reform but is only significantly different in the former.

When focusing on differences in regional characteristics, the data suggest that local active labor market intensities, measured by means of the share of ALMP participants over the number of total unemployed individuals, are higher after the reform, albeit for both treatment and control group. In turn, local unemployment rates remain rather constant. Turning to individual-level measures of support by the local employment agencies, no significant differences in the number of offered jobs become apparent. However, the average number of visits at the local employment agency is slightly lower within the control group after the announcement of the reform, while remaining constant in the treatment group ${ }^{18}$ Finally, differences in the

\footnotetext{
17 Note that there is a small but significant difference with respect to the level of educational attainment across the two groups, which can be related to the German education expansion in the 1970 s.

18 Schmieder and Trenkle (2016) show that caseworkers in German local employment agencies do not treat unemployed job seekers with different eligibility differently across a wide variety of
} 


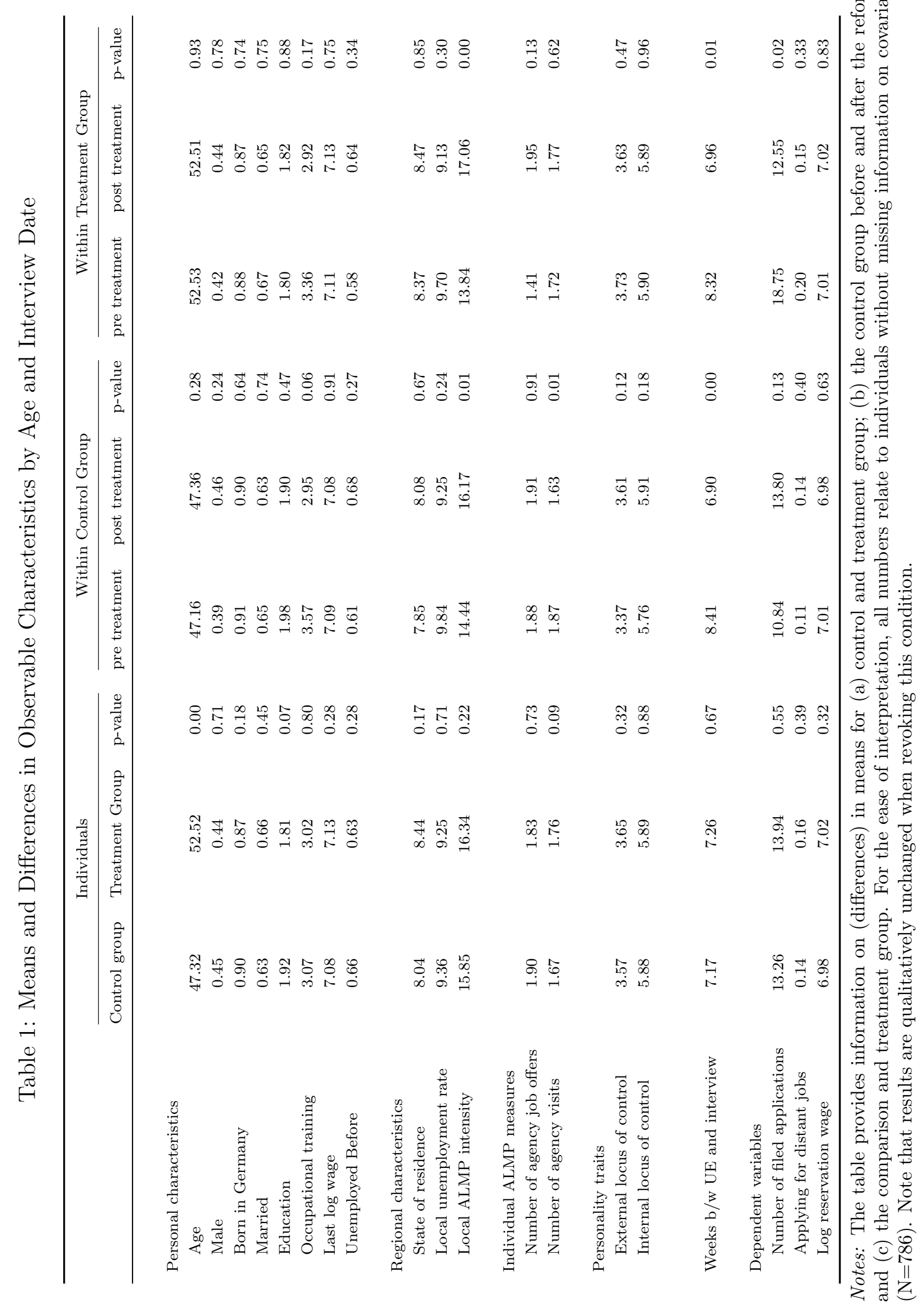


mean number of weeks elapsed between the individuals' unemployment registration and the interview become apparent, decreasing for both age groups from around eight weeks prior to the reform to seven weeks thereafter.

Against the background of these similarities, it is further investigated whether treatment and control group would have followed the same trend in the outcome variables over time in the absence of treatment. In order to investigate this identifying assumption, the respondents are grouped according to their interview date and trends in the average job search intensity and the reservation wage are compared between the treatment and control group 19 Figure 3 visualizes the mean number of applications for the treatment and control group over the course of the survey period. First, the graph provides evidence in favor of a common trend for both groups in the absence of treatment. Average job search intensity is higher for the treatment than for the control group (cf. Table 1), but trends are highly similar for the two groups prior to the reform. The same applies to the two other measures of job search behavior (see Panels (a) and (b) of Figure A.3).

In addition to the visual evidence in favor of a common trend in the absence of the reform, Figure 3 also provides first insights about the treatment effect. While the mean number of job applications for the control group remains rather constant after the announcement of the reform, mean job applications for the treated unemployed immediately decrease and remain at this lower level over the sampling period. As expected, responses in job search effort are more pronounced for those individuals who already knew about the more generous UI scheme when registering as unemployed $\left(I_{b}\right)$ compared to those individuals who updated their expectations about the PBD during the unemployment spell $\left(I_{c}\right)$, thus choosing some part of their job search strategy under the old benefit regime (cf. Figure 2 20

measures (for example, with respect to wage subsidies, personal meetings or sanctions). The observed difference within the control group before and after the reform's announcement should further lead to underestimating the treatment effect if the slightly lower number of agency visits caused job search effort to decline. Nevertheless, I control for (differences in) the number of agency visits in the most comprehensive specification.

19 Recall that the underlying dataset is based on monthly-drawn random samples from the unemployment inflow statistics of the German Federal Employment Agency over the course of one year, such that interview dates vary accordingly.

${ }^{20}$ In the present setting, this only holds true for individuals interviewed in the period between November 13, 2007 and January 15, 2008. 
Figure 3: Trends in the number of job applications

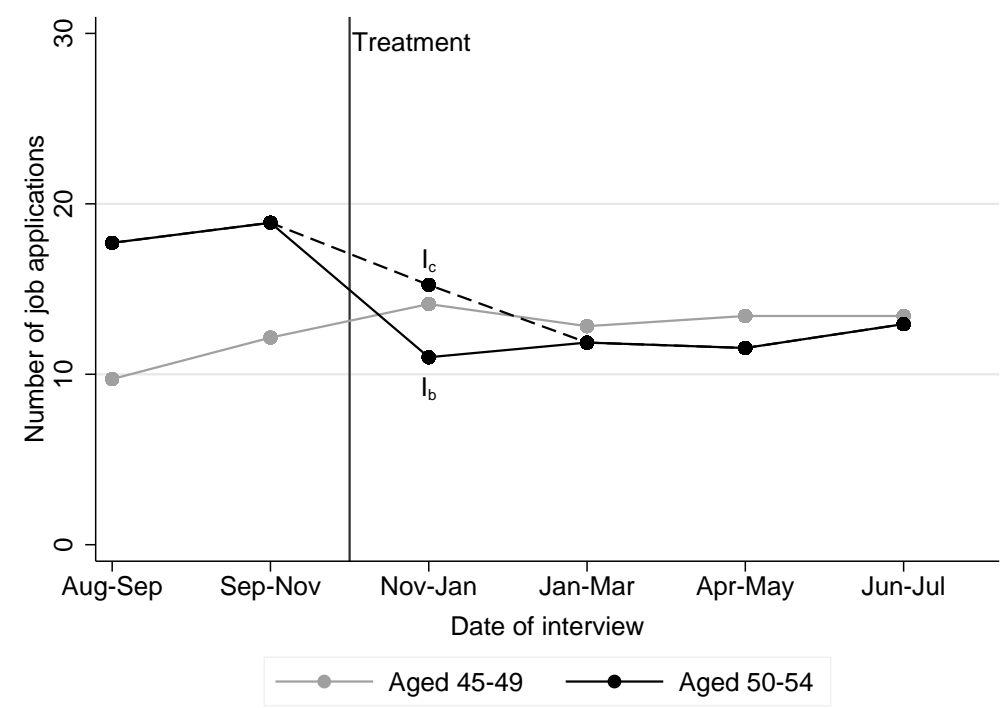

Notes: This graph plots the mean number of job applications for treatment and control group over the survey period.

Similar trends can be observed for the second measure of job search effort, the probability of applying for a job in distant areas (see Panel (a) of Figure A.3). By contrast, reservation wages for both the control and treatment group appear to remain unaffected by the extension of the PBD (see Panel (b) of Figure A.3).

\section{Results}

In the following section, I present the empirical results. Section 5.1 provides the baseline effects of (changes in) the PBD on the three measures of job search behavior, presents the results of different identification tests and explores whether the observed reductions in search effort reflect moral hazard behavior. In Section 5.2 , I apply difference-in-differences and instrumental variables strategies to explicitly investigate whether the UI-induced reductions in search effort translate into lower job-finding rates, as suggested by theory.

\subsection{Effects on job search behavior}

Table 2 provides the corresponding regression results obtained from the differencein-differences model as laid out in equation (1) for the three measures of job search 
behavior: the number of filed applications, the probability of applying for a job that requires moving and the reservation wage.

Column (1) of Panel A shows that the extension of the PBD had a negative and significant effect on the total number of filed applications. In this very simple model, the average number of applications declined by around 8.5 (1.8) applications (per week) in response to the reform. In columns (2) to (5), control variables are successively added to the model to check the robustness of this result. Adding personal characteristics such as the job seekers' gender, level of training or last wage prior to unemployment hardly changes the treatment effect (see column (2)). The same conclusions arise when adding individual-level controls of ALMP intensity (column (3)), or regional controls of the labor market to the model (column (4)). As it has been shown that personality traits may affect job search behavior (Caliendo et al. 2015), information on individuals' personality traits are added in the most comprehensive specification. However, as displayed in column (5), accounting for these variables hardly affects the estimate 21

Panel B of Table 2 presents the corresponding results for my second measure of job search effort. The estimates show a statistically significant and robust negative effect of the PBD on the probability of applying for a job that requires moving once personal characteristics are accounted for. From the results of the most comprehensive specification presented in column (5), it can be inferred that the probability decreases by around 11 percentage points in response to the reform. In line with the results of Panel A, the effect is very robust with respect to the inclusion of additional covariates. Estimates of the treatment effect provided in columns (2)-(5) do not change much when successively adding controls.

By contrast, the estimates presented in Panel C provide no evidence in favor of higher reservation wages due to the increase in the PBD. The estimated treatment effect from the simple model presented in column (1) is close to zero and statistically insignificant. This holds true when successively adding control variables to the model. While this result is in contrast to the prediction of standard job search mod-

\footnotetext{
21 Appendix Table A.5 shows that the results remain unaffected when focusing on the number of applications per week or grouping the number of filed applications as in Caliendo et al. (2015). See Table A.2 for details on these alternative dependent variables.
} 
Table 2: The Effect of the PBD on Job Search Effort and Reservation Wages

\begin{tabular}{|c|c|c|c|c|c|}
\hline \multicolumn{6}{|c|}{ Panel A - Number of job applications } \\
\hline & (1) & $(2)$ & (3) & (4) & $(5)$ \\
\hline \multirow[t]{2}{*}{ Post reform } & $3.114^{*}$ & 3.010 & 2.934 & $3.710^{*}$ & $3.720^{*}$ \\
\hline & $(1.762)$ & $(2.083)$ & $(2.035)$ & $(2.106)$ & $(2.094)$ \\
\hline \multirow[t]{2}{*}{ Aged 50-54 } & $7.566^{* * *}$ & $10.024^{* *}$ & $10.447^{* * *}$ & $9.924^{* *}$ & $9.520^{* *}$ \\
\hline & $(2.815)$ & $(3.974)$ & $(3.890)$ & $(3.958)$ & $(3.916)$ \\
\hline \multirow[t]{2}{*}{ Treatment Effect } & $-8.528^{* * *}$ & $-9.377^{* * *}$ & $-10.223^{* * *}$ & $-9.477^{* * *}$ & $-9.331^{* * *}$ \\
\hline & $(3.032)$ & $(3.226)$ & $(3.167)$ & $(3.246)$ & $(3.218)$ \\
\hline Adjusted- $R^{2}$ & 0.009 & 0.066 & 0.093 & 0.097 & 0.102 \\
\hline Number of observations & 862 & 791 & 787 & 787 & 786 \\
\hline \multicolumn{6}{|c|}{ Panel B - Distant applications } \\
\hline & (1) & $(2)$ & (3) & (4) & (5) \\
\hline \multirow[t]{2}{*}{ Post reform } & 0.033 & 0.069 & 0.068 & 0.056 & 0.058 \\
\hline & $(0.037)$ & $(0.043)$ & $(0.043)$ & $(0.044)$ & $(0.044)$ \\
\hline \multirow[t]{2}{*}{ Aged 50-54 } & 0.070 & $0.131^{*}$ & $0.145^{*}$ & $0.145^{*}$ & $0.150^{*}$ \\
\hline & $(0.053)$ & $(0.077)$ & $(0.076)$ & $(0.078)$ & $(0.079)$ \\
\hline \multirow[t]{2}{*}{ Treatment Effect } & -0.067 & $-0.101^{*}$ & $-0.107^{*}$ & $-0.108^{*}$ & $-0.112^{*}$ \\
\hline & $(0.060)$ & $(0.061)$ & $(0.062)$ & $(0.063)$ & $(0.063)$ \\
\hline Adjusted- $R^{2}$ & -0.001 & 0.163 & 0.160 & 0.154 & 0.153 \\
\hline Number of observations & 862 & 791 & 787 & 787 & 786 \\
\hline
\end{tabular}

Panel C - (Log) reservation wage

(1) (2)

$(3)$

$(4)$

$(5)$

\begin{tabular}{lrrrrr}
\hline Post reform & -0.000 & -0.020 & -0.021 & -0.034 & -0.030 \\
& $(0.069)$ & $(0.046)$ & $(0.047)$ & $(0.048)$ & $(0.048)$ \\
Aged 50-54 & -0.007 & 0.025 & 0.038 & 0.029 & 0.026 \\
& $(0.093)$ & $(0.065)$ & $(0.065)$ & $(0.065)$ & $(0.065)$ \\
Treatment Effect & 0.038 & -0.003 & -0.020 & -0.012 & -0.013 \\
& $(0.102)$ & $(0.058)$ & $(0.061)$ & $(0.062)$ & $(0.062)$
\end{tabular}

\begin{tabular}{lrrrrr} 
Adjusted- $R^{2}$ & -0.003 & 0.640 & 0.646 & 0.643 & 0.644 \\
Number of observations & 687 & 638 & 635 & 635 & 634 \\
\hline Individual controls & No & Yes & Yes & Yes & Yes \\
ALMP measures & No & No & Yes & Yes & Yes \\
Regional controls & No & No & No & Yes & Yes \\
Personality traits & No & No & No & No & Yes \\
\hline
\end{tabular}

Notes: This table provides baseline results of the difference-in-differences strategy laid out in equation (1). Standard errors (in parentheses) are heteroscedasticity robust. The usual significance levels apply: ${ }^{*} p<0.1,{ }^{* *} p<0.05,{ }^{* * *} p<0.01$. 
els, it is in line with recent evidence by Krueger and Mueller (2016) and Schmieder et al. (2016), who show that reservation wages remain rather constant over the spell of unemployment and with respect to changes in UI parameters; for example, because job seekers may potentially "anchor their reservation wage on their previous wage" (Krueger and Mueller, 2016, p.31). Overall, the increase in the PBD is thus found to lower job search effort but to keep reservation wages unaffected.

\subsubsection{Identification tests}

I test the sensitivity of my baseline results by means of three different identification tests. First, I exploit differences in individuals' interview date and their awareness of the reform prior to choosing their job search effort to analyze the job seekers' adjustment to the reform as well as the persistence of the treatment effect. Moreover, I test whether strategic firm behavior may impede the causal interpretation of my findings and run pseudo-treatment tests in the spirit of Rosenbaum (1987) to indirectly test the unconfoundeness assumption of my empirical model. ${ }^{22}$

Adjustment to reform \& persistence of treatment effect As some job seekers registered as unemployed prior to the reform's announcement but were interviewed thereafter (cf. Figure 2), parts of their relevant job search strategy were subject to the less generous PBD scheme. Consequently, reductions in job search effort should be smaller for those individuals compared to job seekers who were fully aware about the extension of the PBD right at the beginning of their unemployment spell. As expected, columns (1) and (2) of Table 3 indicate that the treatment effect is indeed smaller for those job seekers who chose parts of their search effort under the old PBD regime.

This finding is corroborated by the results presented in columns (3) and (4), where the treatment effect is allowed to vary with the job seekers' salience of the reform, defined as the period between the reform's announcement and the individual's respective interview. Job seekers who were interviewed shortly after November 13,

\footnotetext{
22 Appendix Table A.6 further shows that the results are robust to alternative specifications of the error term, i.e. in case of clustering standard errors at the employment agency or federal state $\times$ interview month level.
} 
Table 3: PBD and the Number of Applications - Salience of Treatment

\begin{tabular}{|c|c|c|c|c|c|c|}
\hline & (1) & $(2)$ & $(3)$ & $(4)$ & $(5)$ & $(6)$ \\
\hline Post reform & $\begin{array}{c}3.262^{*} \\
(1.809)\end{array}$ & $\begin{array}{r}3.811 \\
(2.369)\end{array}$ & $\begin{array}{r}2.496 \\
(2.289)\end{array}$ & $\begin{array}{r}3.984 \\
(3.118)\end{array}$ & $\begin{array}{c}4.352^{*} \\
(2.603)\end{array}$ & $\begin{array}{r}4.699 \\
(3.396)\end{array}$ \\
\hline Aged 50-54 & $\begin{array}{c}7.582^{* * *} \\
(2.819)\end{array}$ & $\begin{array}{c}9.304^{* *} \\
(3.858)\end{array}$ & $\begin{array}{l}7.566^{* * *} \\
(2.825)\end{array}$ & $\begin{array}{c}9.144^{* *} \\
(3.857)\end{array}$ & $\begin{array}{c}7.651^{\text {*** }} \\
(2.824)\end{array}$ & $\begin{array}{l}10.033^{* *} \\
(4.042)\end{array}$ \\
\hline Treatment $\times($ Start UE $>$ Nov 12$)$ & $\begin{array}{l}-9.131^{\text {*** }} \\
(3.099)\end{array}$ & $\begin{array}{l}-9.680^{* * *} \\
(3.268)\end{array}$ & & & & \\
\hline Treatment $\times($ Start UE $\leq$ Nov 12$)$ & $\begin{array}{r}-5.994 \\
(3.751)\end{array}$ & $\begin{array}{c}-7.757^{*} \\
(4.035)\end{array}$ & & & & \\
\hline Treatment $\times($ Salience: $1-28$ days $)$ & & & $\begin{array}{r}-4.432 \\
(4.071)\end{array}$ & $\begin{array}{r}-6.151 \\
(4.575)\end{array}$ & & \\
\hline Treatment×(Salience: 28-90 days) & & & $\begin{array}{l}-8.453^{* *} \\
(3.628)\end{array}$ & $\begin{array}{l}-8.937^{* *} \\
(3.748)\end{array}$ & & \\
\hline Treatment $\times($ Salience: $90-180$ days $)$ & & & $\begin{array}{l}-10.448^{* * *} \\
(3.319)\end{array}$ & $\begin{array}{l}-11.051^{\text {*** }} \\
(3.444)\end{array}$ & & \\
\hline Treatment $\times($ Salience: $180+$ days $)$ & & & $\begin{array}{l}-7.984^{* *} \\
(3.622)\end{array}$ & $\begin{array}{l}-8.869^{* *} \\
(3.832)\end{array}$ & & \\
\hline Treatment $\times($ Interview: Nov-Feb) & & & & & $\begin{array}{l}-8.392^{* *} \\
(3.490)\end{array}$ & $\begin{array}{l}-9.312^{* *} \\
(3.733)\end{array}$ \\
\hline Treatment×(Interview: Mar-May) & & & & & $\begin{array}{l}-10.613^{* * *} \\
(3.442)\end{array}$ & $\begin{array}{l}-11.212^{* * *} \\
(3.523)\end{array}$ \\
\hline Treatment×(Interview: Jun-Jul) & & & & & $\begin{array}{l}-8.633^{* *} \\
(3.841)\end{array}$ & $\begin{array}{l}-9.050^{* *} \\
(4.126)\end{array}$ \\
\hline Adjusted- $R^{2}$ & 0.009 & 0.107 & 0.007 & 0.107 & 0.009 & 0.126 \\
\hline Controls & No & Yes & No & Yes & No & Yes \\
\hline Number of observations & 862 & 786 & 862 & 786 & 722 & 661 \\
\hline
\end{tabular}

Notes: This table provides results of the difference-in-differences strategy laid out in equation (1), focusing on differential effects due to the timing/salience of the treatment. The dependent variable is the number of applications. In Columns (5) and (6), all individuals who became unemployed prior to the reform but were interviewed thereafter are dropped. Standard errors (in parentheses) are heteroscedasticity robust. The usual significance levels apply: ${ }^{*} p<0.1$, ${ }^{* *} p<0.05,{ }^{* * *} p<0.01$. 
2007 (up to four weeks) did not significantly reduce their job search effort compared to the non-treated job seekers. In contrast, treated individuals who were interviewed more than four weeks after the reform's announcement significantly reduced their job search effort.

While the previous results thus corroborate the expected adjustment mechanism in response to the reform, the treatment effect is found to remain stable over time. When omitting those job seekers who updated their expectations about the PBD during the relevant search spell, estimated treatment effects are very similar over the survey period (see columns (5) and (6) of Table 3). These findings also hold true when focusing on the probability of applying for a distant job (see Appendix Table A.3.

Strategic timing of layoffs As highlighted above, strategic timing of layoffs may impede the causal interpretation of my previous findings. Although strict employment protection laws in Germany limit the scope for strategic firing decisions of firm: ${ }^{23}$, the robustness of the study's findings is tested by limiting the analysis to those individuals who became unemployed due to plant closure, the termination of a temporary contract and alike. Although the number of observations significantly decreases (by roughly two-thirds), the results presented in Appendix Table A.7 demonstrate that the estimates remain robust to this constraint 24

Pseudo treatment test Further recall that identification of the underlying empirical model relies on the assumption that individuals are randomly assigned to treatment and control group and are similar in terms of observable and unobservable characteristics. While observable characteristics are indeed similar among treatment, comparison and control groups (cf. Table 1), unobservable variables may still violate the unconfoundedness assumption. Following Rosenbaum (1987), this as-

23 Dismissal of regular workers is subject to a variety of legal regulations. Advanced notice of layoff is required by law, with the period of notice increasing with the worker's tenure $(\S 622$, German Civil Code). Additional rules (Kündigungsschutzgesetz) apply for plants that employ at least ten full-time equivalent workers. Rates of job destruction and creation mirror these legislative features of the German labor market: job and worker flow rates are around $50 \%$ lower than in the U.S. (Bachmann et al. 2013).

${ }^{24}$ When focusing on the probability of applying for a distant job, the treatment effect is significant at the $11 \%$ level $(\rho=0.110)$. 
sumption is indirectly tested by estimating the causal effect of the treatment for two groups of individuals that were unaffected by the reform (workers aged 40 to 44 and 45 to 49 , respectively), with one of the two groups (the older age group) being arbitrarily considered as pseudo-treated. No evidence of any pseudo treatment effect on the outcomes would strengthen the claim of unconfoundedness. Table A.8 in the Appendix shows support for the identifying assumption, given that pseudo-treatment effects for all three measures of job search behavior are small and statistically insignificant ${ }^{25}$

\subsubsection{Explaining the mechanism}

I next aim to explore whether the observed reductions in job search effort reflect moral hazard behavior or whether the role of liquidity effects must also be accounted for (Chetty, 2008). In order to investigate the underlying mechanism at play, I analyze whether UI-induced reductions in job search effort vary with (i) the tightness of individuals' respective local labor market, (ii) the length of the current unemployment spell, and (iii) individuals' financial situation. I account for differences in local labor markets given that a reduction in job search effort may be less costly in regions with low unemployment rates. Stronger treatment effects in prosperous regions may thus indicate moral hazard behavior. As indicated in columns (1) and (2) of Table 4, treatment effects are indeed strongest for individuals who live in regions with low or medium unemployment rates. By contrast, individuals subject to significant local unemployment do not substantially reduce their job search effort.

As a second exercise, I exploit variation in the time period between individuals' unemployment registration and interview date, which varies from around four to sixteen weeks. Columns (3) and (4) of Table 4 show that individuals seem to postpone their job search effort in response to the extension of the PBD, given that the treatment effect is particularly strong at the very beginning of the unemployment spell but becomes smaller and insignificant over the course of unemployment. I take this postponement of search effort as suggestive evidence in favor of moral hazard

25 Note that, except for the mean age, both groups are highly similar regarding observable characteristics. The corresponding descriptive statistics are available upon request. 
Table 4: Exploring the Mechanism - PBD and the Number of Applications

\begin{tabular}{|c|c|c|c|c|c|c|}
\hline Dep. Var.: Job applications & (1) & $(2)$ & $(3)$ & $(4)$ & $(5)$ & (6) \\
\hline Post reform & $\begin{array}{c}2.961^{*} \\
(1.756)\end{array}$ & $\begin{array}{c}3.750^{*} \\
(2.086)\end{array}$ & $\begin{array}{c}3.919^{* *} \\
(1.846)\end{array}$ & $\begin{array}{r}2.999 \\
(2.144)\end{array}$ & $\begin{array}{r}2.897 \\
(1.839)\end{array}$ & $\begin{array}{r}3.550 \\
(2.166)\end{array}$ \\
\hline Aged 50-54 & $\begin{array}{c}7.562^{* * *} \\
(2.809)\end{array}$ & $\begin{array}{c}9.615^{* *} \\
(3.910)\end{array}$ & $\begin{array}{c}7.845^{* * *} \\
(2.836)\end{array}$ & $\begin{array}{c}9.627^{* *} \\
(3.945)\end{array}$ & $\begin{array}{c}7.377^{* *} \\
(2.884)\end{array}$ & $\begin{array}{c}9.437^{* *} \\
(3.994)\end{array}$ \\
\hline Treatment $\times($ Low UE rate $)$ & $\begin{array}{l}-9.167^{* * *} \\
(3.194)\end{array}$ & $\begin{array}{l}-10.265^{\text {*** }} \\
(3.472)\end{array}$ & & & & \\
\hline Treatment $\times($ Moderate UE rate $)$ & $\begin{array}{l}-9.383^{* * *} \\
(3.580)\end{array}$ & $\begin{array}{l}-10.226^{* * *} \\
(3.630)\end{array}$ & & & & \\
\hline Treatment $\times($ High UE rate $)$ & $\begin{array}{r}-5.579 \\
(3.462)\end{array}$ & $\begin{array}{c}-5.853 \\
(3.652)\end{array}$ & & & & \\
\hline Treatment×(Weeks UE-Interview:4-5) & & & $\begin{array}{l}-8.574^{* * *} \\
(3.054)\end{array}$ & $\begin{array}{l}-8.843^{\text {*** }} \\
(3.249)\end{array}$ & & \\
\hline Treatment×(Weeks UE-Interview:6-8) & & & $\begin{array}{l}-9.952^{* * *} \\
(3.216)\end{array}$ & $\begin{array}{l}-10.826^{\text {*** }} \\
(3.489)\end{array}$ & & \\
\hline Treatment $\times($ Weeks UE-Interview: $9+)$ & & & $\begin{array}{r}-6.561 \\
(4.067)\end{array}$ & $\begin{array}{r}-6.027 \\
(4.212)\end{array}$ & & \\
\hline Treatment $\times($ No debts $)$ & & & & & $\begin{array}{l}-7.913^{* * *} \\
(3.059)\end{array}$ & $\begin{array}{l}{ }^{*}-8.509^{* * *} \\
(3.253)\end{array}$ \\
\hline Treatment $\times($ Debts $)$ & & & & & $\begin{array}{l}-8.674^{* *} \\
(3.466)\end{array}$ & $\begin{array}{l}-9.816^{* * *} \\
(3.690)\end{array}$ \\
\hline Adjusted- $R^{2}$ & 0.011 & 0.100 & 0.023 & 0.106 & 0.007 & 0.098 \\
\hline Controls & No & Yes & No & Yes & No & Yes \\
\hline Number of observations & 862 & 786 & 862 & 786 & 854 & 780 \\
\hline
\end{tabular}

Notes: This table provides regression results of the difference-in-differences model laid out in equation (1), allowing for heterogeneous treatment effects by (a) local unemployment rates, (b) the length of the unemployment spell prior to the interview, and (c) individuals' debts. Standard errors (in parentheses) are heteroscedasticity robust. The usual significance levels apply: ${ }^{*} p<$ $0.1,{ }^{* *} p<0.05,{ }^{* * *} p<0.01$. 
behavior. In a final step, I also account for the potential role of liquidity effects by using information on debts as a proxy for financial constraints. More pronounced reductions in job search effort by job seekers facing debts (which relates to around $50 \%$ of the sample) might indeed provide evidence for the presence of liquidity effects. However, columns (5) and (6) of Table 4 provide no evidence of stronger responses among the indebted. When focusing on the probability of applying for a distant job, similar - albeit less pronounced - findings emerge (see Appendix Table A.4).

\subsection{PBD, search effort and job finding}

In this section, I next test whether the UI-induced reductions in search effort translate into lower job-finding rates, as suggested by theory. Based on the difference-indifferences model laid out in equation (1), I first present reduced form estimates in Panel A of Table 5. In line with theory and previous empirical evidence, the results demonstrate that the extension of the PBD significantly reduced individuals' shortrun job-finding probability ${ }^{26}$ More precisely, the results displayed in column (1) suggest that the extension of the PBD by twelve weeks reduced the probability of being employed at the time of the first interview by around 9.4 percentage points ${ }^{27}$ Interestingly, job-finding probabilities more strongly decline for those individuals who had been unemployed prior to this current spell (see column (2)), as well as those living in regions subject to medium or high local unemployment rates (column (3)). As individuals with and without previous unemployment experience reduced job search effort to a similar extent (cf. Tables A.9 and A.10), differences in exit rates might thus be due to scarring effect:28 or unobserved differences in the quality

${ }^{26}$ In the analysis, a job seeker is considered to exit from unemployment in case she takes up employment that is subject to social security contributions.

27 For example, for a 53 year old women with secondary education and monthly net earnings of 1,300 Euros before unemployment, the short-run job-finding probability decreases from about 16 to $9 \%$. The size of this effect appears reasonable when being compared to estimates from the literature that apply comparable identification strategies (see, for example, Hunt (1995); Van Ours and Vodopivec (2006, 2008)).

28 A large body of literature points to the long-term scarring effects of unemployment (see, for example, Arulampalam (2001) and Gregg (2001)). Recent work by Eriksson and Rooth (2014), however, challenges this finding. Accounting for heterogeneous effects unaccounted for in earlier studies, they provide no evidence in favor of employers selecting applicants with respect to past 
of applications. Moreover, reduced job search effort appears to be more costly in tight labor markets, given that reductions in job search effort do not prolong spells of unemployment in prospering local economies but significantly reduce short-run job findings chances in local labor markets subject to moderate or high unemployment rates.

Against the backdrop of these reduced form effects, I further apply instrumental variables techniques to explicitly investigate the direct effect of job search effort on unemployment durations. Here, endogeneity in individuals' job search effort (measured by the number of filed applications) is accounted for by instrumenting this variable with the reform's induced variation in the PBD (the treatment indicator variable), assuming that changes in the PBD have no effect on the job finding probability other than through the observed reduction in job search effort. The corresponding first stage regression is thus given by the difference-in-differences model (see column (5) of Panel A in Table 2).

Panel $\mathrm{B}$ of Table 5 provides the corresponding results of this instrumental variables approach ${ }^{29}$ Column (1) shows that search effort - measured by the number of filed applications - has a significant and positive effect on the short-run job finding probability. Evaluated at the mean, a 10 percent increase in the number of filed applications is found to increase the probability of exiting from unemployment prior to the first interview by about 1.3 percentage points. Put differently, one additional application thus raises the short-run job-finding rate by around one percentage point. However, columns (2) and (3) of Panel B suggest that the underlying relationship might be non-linear in nature, given that both transformations of the job search measure suggest positive but diminishing returns for the number of filed applications.

\section{Conclusion}

To date, a large body of empirical literature has shown that more generous UI schemes significantly prolong spells of non-employment. While this finding is com-

spells of unemployment.

29 Note that all models seem to be well identified: the Kleibergen-Paap test statistics suggest that the instrument is relevant and not weak. 
Table 5: PBD, Job Search and Exit from Unemployment

Panel A - Reduced form Estimates

Dep. Variable: Exit to employment
(1) (2)

$-0.094^{*}$

$(0.050)$

Treatment $\times$ (Not UE before)

$(0.054)$

$-0.105^{* *}$

$(0.053)$

$-0.065$

$-0.121^{* *}$

$(0.056)$

$-0.107^{*}$

$(0.063)$

0.400

0.399

Adjusted- $R^{2}$

0.400

Yes

Yes

Panel B - Instrumental Variables Estimates

(1)

$(2)$

(3)

Dep. Variable: Exit to employment

Number of applications

$$
\begin{gathered}
0.010^{*} \\
(0.006)
\end{gathered}
$$

Square Root(no. of applications)

$$
\begin{gathered}
0.080^{*} \\
(0.047)
\end{gathered}
$$

Cube Root(no. of applications)

\begin{tabular}{lrrr} 
Adjusted- $R^{2}$ & 0.130 & 0.167 & 0.144 \\
Controls & Yes & Yes & Yes \\
Underidentification Test & 8.931 & 12.06 & 11.09 \\
Weak Identification Test & 8.409 & 11.57 & 10.68 \\
\hline
\end{tabular}

Notes: Regression results presented in Panel A are based on the difference-in-differences model laid out in equation (1). Regression results presented in Panel B are based on Instrumental Variables. Standard errors (in parentheses) are heteroscedasticity robust. The usual significance levels apply: ${ }^{*} p<0.1,{ }^{* *} p<0.05,{ }^{* * *} p<0.01$. 
monly attributed to strategic job search behavior and UI-induced moral hazard, empirical evidence on the assumed relationship is scarce. Using quasi-experimental variation in the PBD for one specific age group of workers in Germany paired with direct information on the job search behavior of unemployed individuals, this paper adds to the existing evidence by providing causal estimates of the effect of the PBD on job search effort, reservation wages and the associated length of non-employment.

The results of this analysis lend considerable support to the existence of UIinduced strategic job search behavior, with the extension of the PBD causing a considerable decrease in job search effort, as measured by the number of filed applications and the probability of applying for jobs that require moving. In line with recent evidence (see, among others, Krueger and Mueller (2016) and Schmieder et al. (2016)) but in contrast to standard job search theory, reservation wages are, however, not found to increase in response to the extension of the PBD.

In line with the theoretical predictions of standard job search models, the paper further demonstrates that the UI-induced reductions in search effort are accompanied by a significant reduction in the short-run job-finding probability. Instrumental variables estimates further provide first causal evidence of the direct effect of job search effort on job-finding rates. Evaluated at the mean, one additional application is found to increase the short-run job-finding probability by around one percentage point. However, the underlying relationship appears to be non-linear in nature, given that returns to job search effort are positive but diminishing.

In terms of future research, it would be particularly interesting to revisit my results with comparable datasets that offer information on job search behavior over the entire course of the individuals' unemployment spell to investigate the longerrun consequences of (changes in) the PBD on job search effort and unemployment durations. 


\section{References}

Arni, P., M. Caliendo, S. Künn, and K. F. Zimmermann (2014). The IZA evaluation dataset survey: a scientific use file. IZA Journal of European Labor Studies 3(6).

Arni, P. and A. Schiprowski (2015). The Effects of Binding and Non-Binding Job Search Requirements. IZA Discussion Paper 8951.

Arulampalam, W. (2001). Is Unemployment Really Scarring? Effects of Unemployment Experiences on Wages. Economic Journal 111(475), 585-606.

Bachmann, R., C. Bayer, S. Seth, and F. Wellschmied (2013). Cyclicality of Job and Worker Flows: New Data and a New Set of Stylized Facts. IZA Discussion Paper 7192.

Baker, S. R. and A. Fradkin (2016). The Impact of Unemployment Insurance on Job Search: Evidence from Google Search Data. mimeo.

Caliendo, M., D. A. Cobb-Clark, and A. Uhlendorf (2015). Locus of Control and Job Search Strategies. Review of Economics and Statistics 97(1), 88-103.

Card, D., R. Chetty, and A. Weber (2007). Cash-on-Hand and Competing Models of Intertemporal Behavior: New Evidence from the Labor Market. Quarterly Journal of Economics 122(4), 1511-1560.

Card, D. and P. B. Levine (2000). Extended benefits and the duration of UI spells: evidence from the New Jersey extended benefit program. Journal of Public Economics 78(1-2), 107-138.

Chetty, R. (2008). Moral hazard versus liquidity and optimal unemployment insurance. Journal of Political Economy 116(2), 173-234.

Eriksson, S. and D. O. Rooth (2014). Do Employers Use Unemployment as a Sorting Criterion When Hiring? Evidence from a Field Experiment. American Economic Review 104 (3), 1014-1039.

Garthwaite, C., T. Gross, and M. Notowidigdo (2014). Public Health Insurance, Labor Supply, and Employment Lock. Quarterly Journal of Economics 129(2), 653-696.

Gregg, P. (2001). The Impact of Youth Unemployment on Adult Unemployment in the NCDS. Economic Journal 111(475), 626-653.

Hunt, J. (1995). The Effect of Unemployment Compensation on Unemployment Duration inGermany. Journal of Labor Economics 13, 88-120.

Katz, J. and B. Meyer (1990). The Impact of the Potential Duration of Unemployment Benefits on the Duration of Unemployment. Journal of Public Economics 41(1), 45-72.

Krueger, A. B. and A. I. Mueller (2016). A Contribution to the Empirics of Reservation Wages. American Economic Journal: Economic Policy 8(1), 142-179. 
Kyyrä, T. and V. Ollikainen (2008). To search or not to search? The effects of UI benefit extension for the older unemployed. Journal of Public Economics 92(1011), 2048-2070.

Lalive, R., J. van Ours, and J. Zweimüller (2006). How Changes in Financial Incentives Affect the Duration of Unemployment. Review of Economic Studies 73(4), 1009-1038.

Marinescu, I. (2015). The General Equilibrium Impacts of Unemployment Insurance: Evidence from a Large Online Job Board. mimeo.

Rosenbaum, P. (1987). The Role of a Second Control Group in an Observational Study. Statistical Science 2(3), 292-306.

Schmieder, J. F. and S. Trenkle (2016). Disincentive Effects of Unemployment Benefits and the Role of Caseworkers. IZA Discussion Paper 9868.

Schmieder, J. F., T. von Wachter, and S. Bender (2012). The Effects of Extended Unemployment Insurance Over The Business Cycle: Evidence From Regression Discontinuity Estimates Over 20 Years. The Quarterly Journal of Economics 12\%, 701-752.

Schmieder, J. F., T. von Wachter, and S. Bender (2016). The effect of unemployment benefits and nonemployment durations on wages. American Economic Review 106(3), 739-777.

Van Ours, J. C. and M. Vodopivec (2006). How Shortening the Potential Duration of Unemployment Benefits Affects the Duration of Unemployment: Evidence from a Natural Experiment. Journal of Labor Economics 24 (2), 351-378.

Van Ours, J. C. and M. Vodopivec (2008). Does reducing unemployment insurance generosity reduce job match quality? Journal of Public Economics 92(3-4), 684695. 


\section{A Appendix}

Figure A.1: (Seasonal-adjusted) Unemployment Rate (2006-2010)

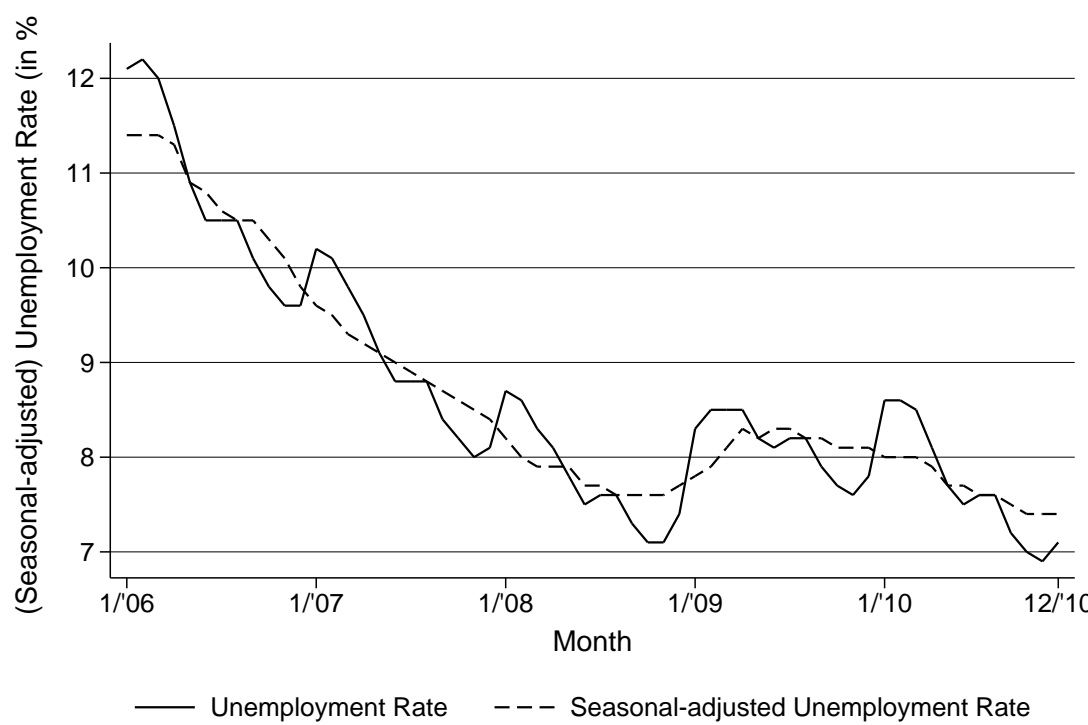

Notes: The graph plots monthly (seasonal-adjusted) unemployment rates from January 2006 to December 2010 for Germany. The data are provided by the German Federal Employment Agency.

Figure A.2: Number of Granted Employment Integration Subsidies (2006-2010)

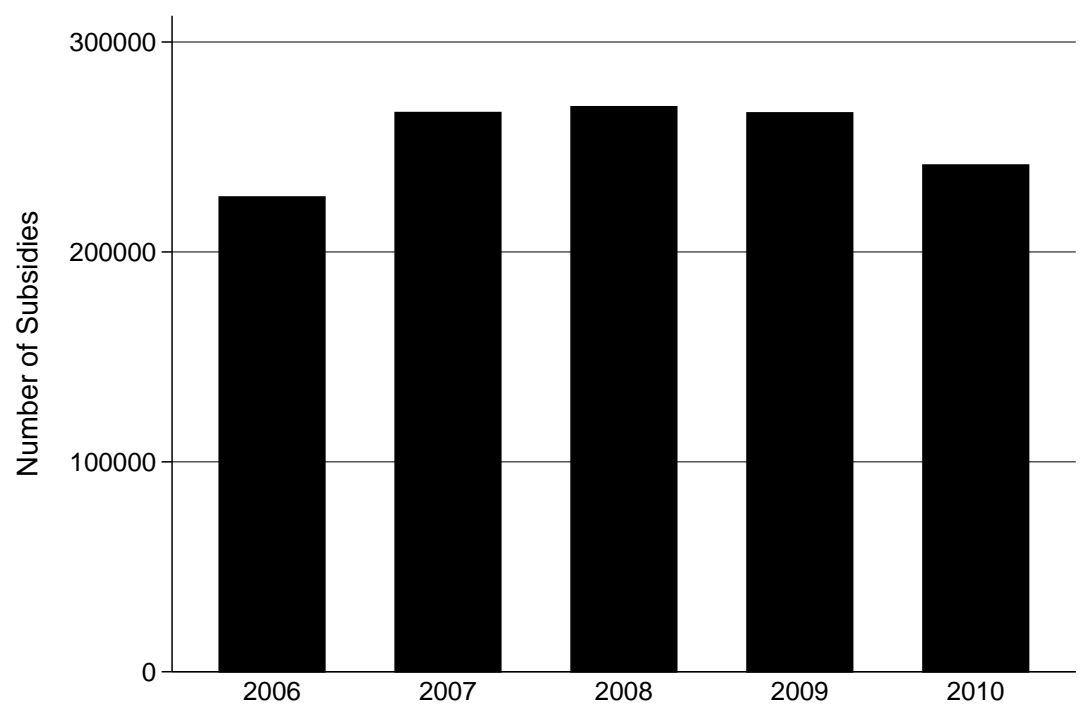

Notes: The graph plots the annual number of granted employment integration subsidies. The data are provided by the German Federal Employment Agency. 
Figure A.3: Trends in Outcome Variables over Time

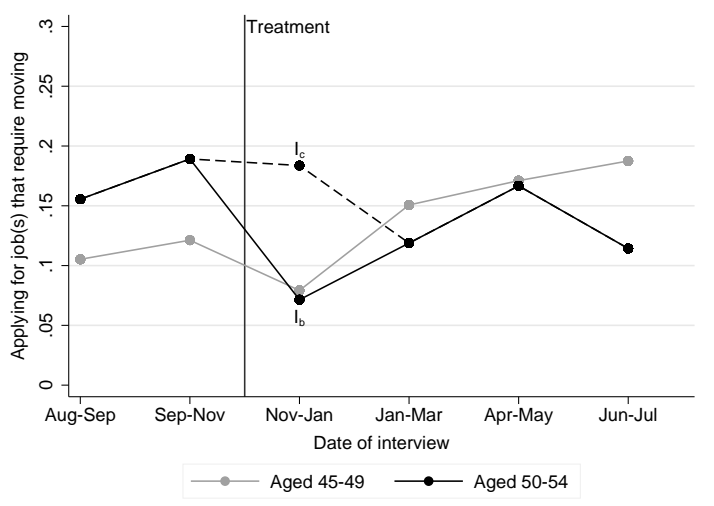

(a) Appyling for distant jobs

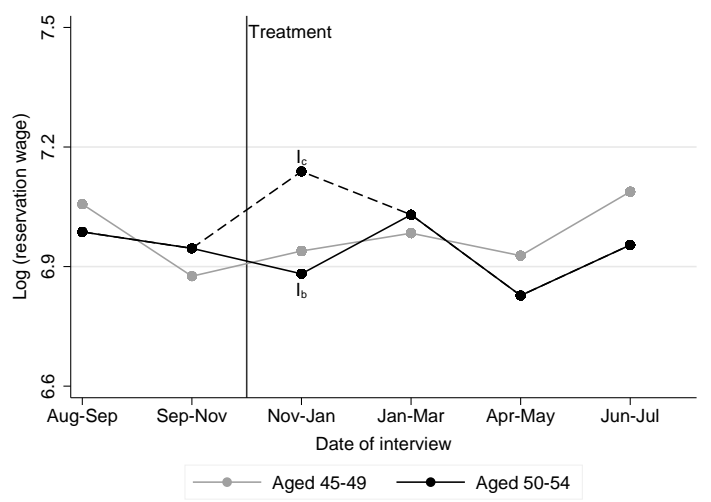

(b) Log reservation wage

Notes: This figure displays the variation in the two outcome variables (the probability of applying for distant jobs, the log reservation wage) for the treatment and control group over the survey period.

Table A.1: Claimants' age, Length of UI Contributions and PBD

\section{Before January 12008}

\begin{tabular}{ccccccc} 
Period of UI contribution (months) & 12 & 16 & 20 & 24 & 30 & 36 \\
$\quad$ \& Age of eligible person .. or above & & & & & 55 & 55 \\
& & & & & & \\
& 6 & 8 & 10 & 12 & 15 & 18 \\
\hline
\end{tabular}

\section{Since January 12008}

\begin{tabular}{cccccccc}
$\begin{array}{c}\text { Period of UI contribution (months) } \\
\text { \& Age of eligible person .. or above }\end{array}$ & 12 & 16 & 20 & 24 & 30 & 36 & 48 \\
& & & & & 50 & 55 & 58 \\
& 6 & 8 & 10 & 12 & 15 & 18 & 24 \\
\hline
\end{tabular}

Notes: The table shows the relationship between the claimant's age, length of UI contributions and the potential benefit duration. Note that prior to the reform, the qualifying period determining the length of coverage was three years. It was extended to five years by January 1, 2008. 
Table A.2: Descriptive Statistics on (In)dependent Variables

\begin{tabular}{|c|c|c|c|c|c|}
\hline & Mean & Std Deviation & Minimum & Maximum & Observations \\
\hline \multicolumn{6}{|l|}{ Dependent variables } \\
\hline Number of filed applications & 13.34 & 15.72 & 0.00 & 120.00 & 862 \\
\hline Applying for distant jobs & 0.14 & 0.35 & 0.00 & 1.00 & 862 \\
\hline Log reservation wage & 6.98 & 0.49 & 5.30 & 8.99 & 687 \\
\hline Filed applications per week & 1.86 & 2.26 & 0.00 & 25.00 & 826 \\
\hline Application index & 3.48 & 1.46 & 1.00 & 6.00 & 862 \\
\hline Exit to employment & 0.10 & 0.30 & 0.00 & 1.00 & 862 \\
\hline \multicolumn{6}{|l|}{ Personal characteristics } \\
\hline Age & 49.57 & 2.95 & 45.00 & 55.00 & 862 \\
\hline Age (squared) & $2,479.32$ & 295.41 & $2,025.00$ & $3,043.36$ & 862 \\
\hline Male & 0.43 & 0.50 & 0.00 & 1.00 & 862 \\
\hline Born in Germany & 0.89 & 0.32 & 0.00 & 1.00 & 862 \\
\hline Married & 0.65 & 0.48 & 0.00 & 1.00 & 860 \\
\hline Education & 1.87 & 0.77 & 1.00 & 4.00 & 860 \\
\hline Occupational training & 3.07 & 2.64 & 0.00 & 9.00 & 853 \\
\hline Last wage & $1,413.82$ & 969.88 & 400.00 & $12,000.00$ & 803 \\
\hline Unemployed Before & 0.65 & 0.48 & 0.00 & 1.00 & 861 \\
\hline Quarter of interview & 2.44 & 1.14 & 1.00 & 4.00 & 862 \\
\hline \multicolumn{6}{|l|}{ Regional characteristics } \\
\hline Local unemployment rate & 9.24 & 3.99 & 3.00 & 17.00 & 862 \\
\hline Squared local UE rate & 101.21 & 80.97 & 9.00 & 289.00 & 862 \\
\hline Local ALMP intensity & 16.07 & 5.53 & 7.00 & 30.00 & 862 \\
\hline Squared local ALMP intensity & 288.72 & 194.75 & 49.00 & 900.00 & 862 \\
\hline State of residence & 8.18 & 4.13 & 1.00 & 16.00 & 862 \\
\hline \multicolumn{6}{|l|}{ Individual ALMP measures } \\
\hline Number of agency job offers & 1.53 & 1.89 & 0.00 & 6.00 & 859 \\
\hline Number of agency visits & 1.69 & 0.72 & 0.00 & 4.00 & 861 \\
\hline \multicolumn{6}{|l|}{ Personality traits } \\
\hline Internal locus of control & 5.87 & 0.95 & 1.33 & 7.00 & 861 \\
\hline External locus of control & 3.59 & 1.17 & 1.00 & 7.00 & 861 \\
\hline
\end{tabular}

Note: This table provides descriptive statistics for the underlying estimation sample. Note that the application index consists of six categories: zero applications ( $6.8 \%) ; 1-4$ applications $(23.3 \%)$; $5-9$ applications (22.3\%); 9-19 applications (22.9\%); 20-29 applications (12.3\%); and 30+ applications (12.4\%). 
Table A.3: PBD and Applying for Jobs in Distant Areas - Salience of Treatment

\begin{tabular}{|c|c|c|c|c|c|c|}
\hline & $(1)$ & $(2)$ & $(3)$ & $(4)$ & $(5)$ & $(6)$ \\
\hline Post reform & $\begin{array}{r}0.054 \\
(0.039)\end{array}$ & $\begin{array}{l}0.132^{* * *} \\
0.049)\end{array}$ & $\begin{array}{r}0.091^{*} \\
(0.054)\end{array}$ & $\begin{array}{c}0.152^{* *} \\
(0.065)\end{array}$ & $\begin{array}{r}0.089 \\
(0.061)\end{array}$ & $\begin{array}{r}0.130 * \\
(0.069)\end{array}$ \\
\hline Aged 50-54 & $\begin{array}{r}0.072 \\
(0.053)\end{array}$ & $\begin{array}{r}0.152 * \\
0.079)\end{array}$ & $\begin{array}{r}0.070 \\
(0.053)\end{array}$ & $\begin{array}{r}0.148^{*} \\
(0.079)\end{array}$ & $\begin{array}{r}0.071 \\
(0.054)\end{array}$ & $\begin{array}{c}0.188^{* *} \\
(0.085)\end{array}$ \\
\hline Treatment Effect $\times($ Start UE spell $>$ Nov 12$)$ & $\begin{array}{r}-0.096 \\
(0.062)\end{array}$ & $\begin{array}{l}-0.148^{* *} \\
0.066)\end{array}$ & & & & \\
\hline Treatment Effect $\times($ Start UE spell $\leq$ Nov 12$)$ & $\begin{array}{r}0.033 \\
(0.079)\end{array}$ & -0.044 & & & & \\
\hline Treatment Effect $\times($ Salience: $1-28$ days $)$ & & & $\begin{array}{r}0.061 \\
(0.097)\end{array}$ & $\begin{array}{r}0.002 \\
(0.098)\end{array}$ & & \\
\hline Treatment Effect $\times($ Salience: $28-90$ days $)$ & & & $\begin{array}{r}-0.074 \\
(0.072)\end{array}$ & $\begin{array}{r}-0.117 \\
(0.074)\end{array}$ & & \\
\hline Treatment Effect $\times($ Salience: $90-180$ days $)$ & & & $\begin{array}{r}-0.067 \\
(0.070)\end{array}$ & $\begin{array}{l}-0.130 \text { * } \\
(0.070)\end{array}$ & & \\
\hline Treatment Effect $\times($ Salience: $180+$ days $)$ & & & $\begin{array}{r}-0.127 \\
(0.079)\end{array}$ & $\begin{array}{c}-0.141 \text { * } \\
(0.085)\end{array}$ & & \\
\hline Treatment Effect $\times($ Interview: Nov-Feb) & & & & & $\begin{array}{r}-0.092 \\
(0.071)\end{array}$ & $\begin{array}{l}-0.165^{* *} \\
(0.074)\end{array}$ \\
\hline Treatmnet Effect $\times($ Interview: Mar-May) & & & & & $\begin{array}{r}-0.062 \\
(0.078)\end{array}$ & $\begin{array}{l}-0.157^{* *} \\
(0.079)\end{array}$ \\
\hline Treatment Effect $\times($ Interview: Jun-Jul $)$ & & & & & $\begin{array}{c}-0.138^{*} \\
(0.081)\end{array}$ & $\begin{array}{r}-0.128 \\
(0.092)\end{array}$ \\
\hline Adjusted- $R^{2}$ & 0.003 & 0.163 & -0.002 & 0.152 & -0.005 & 0.159 \\
\hline Controls & No & Yes & No & Yes & No & Yes \\
\hline Number of observations & 862 & 786 & 862 & 786 & 722 & 661 \\
\hline
\end{tabular}

Notes: This table provides regression results of the difference-in-differences model laid out in equation (1), focusing on differential effects due to the timing/salience of the treatment. The dependent variable indicates whether individuals apply for jobs that require moving. In Columns (5) and (6), all individuals who became unemployed prior to the reform but were interviewed thereafter are dropped. Standard errors (in parentheses) are heteroscedasticity robust. The usual significance levels apply: ${ }^{*} p<0.1,{ }^{* *} p<0.05,{ }^{* * *} p<0.01$. 
Table A.4: Exploring the mechanism - PBD and Applying for Jobs in Distant Areas

\begin{tabular}{|c|c|c|c|c|c|c|}
\hline Dep. Var.: Distant Applications & (1) & $(2)$ & $(3)$ & (4) & $(5)$ & $(6)$ \\
\hline \multirow[t]{2}{*}{ Post reform } & 0.031 & 0.064 & 0.036 & 0.054 & 0.028 & 0.053 \\
\hline & $(0.037)$ & $(0.045)$ & $(0.038)$ & $(0.044)$ & $(0.038)$ & $(0.045)$ \\
\hline \multirow[t]{2}{*}{ Aged 50-54 } & 0.069 & $0.156^{* *}$ & 0.072 & $0.150^{*}$ & 0.064 & $0.142^{*}$ \\
\hline & $(0.053)$ & $(0.079)$ & $(0.053)$ & $(0.079)$ & $(0.054)$ & $(0.080)$ \\
\hline \multirow[t]{2}{*}{ Treatment $\times($ Low UE rate $)$} & -0.034 & -0.105 & & & & \\
\hline & $(0.069)$ & $(0.072)$ & & & & \\
\hline \multirow[t]{2}{*}{ Treatment $\times$ (Moderate UE rate) } & $-0.121^{*}$ & $-0.148^{* *}$ & & & & \\
\hline & $(0.064)$ & $(0.067)$ & & & & \\
\hline \multirow[t]{2}{*}{ Treatment $\times($ High UE rate $)$} & -0.030 & -0.053 & & & & \\
\hline & $(0.079)$ & $(0.083)$ & & & & \\
\hline \multirow[t]{2}{*}{ Treatment $\times($ Weeks UE-Interview:4-5) } & & & -0.040 & -0.110 & & \\
\hline & & & $(0.075)$ & $(0.078)$ & & \\
\hline \multirow[t]{2}{*}{ Treatment×(Weeks UE-Interview:6-8) } & & & -0.092 & $-0.124^{*}$ & & \\
\hline & & & $(0.065)$ & $(0.068)$ & & \\
\hline \multirow[t]{2}{*}{ Treatment $\times($ Weeks UE-Interview: $9+)$} & & & -0.043 & -0.089 & & \\
\hline & & & $(0.076)$ & $(0.080)$ & & \\
\hline \multirow[t]{2}{*}{ Treatment $\times($ No problematic debts $)$} & & & & & -0.082 & $-0.126^{*}$ \\
\hline & & & & & $(0.062)$ & $(0.064)$ \\
\hline \multirow[t]{2}{*}{ Treatment $\times($ Problematic debts $)$} & & & & & -0.039 & -0.080 \\
\hline & & & & & $(0.069)$ & $(0.073)$ \\
\hline Adjusted- $R^{2}$ & -0.000 & 0.151 & -0.004 & 0.150 & -0.003 & 0.152 \\
\hline Controls & No & Yes & No & Yes & No & Yes \\
\hline Number of observations & 862 & 786 & 862 & 786 & 854 & 780 \\
\hline
\end{tabular}

Notes: This table provides regression results of the difference-in-differences model laid out in equation (1), allowing for heterogeneous treatment effects by (a) local unemployment rates, (b) the length of the unemployment spell prior to the interview, and (c) individuals' debts. Standard errors (in parentheses) are heteroscedasticity robust. The usual significance levels apply: ${ }^{*} p<0.1,{ }^{* *} p<0.05,{ }^{* * *} p<0.01$. 
Table A.5: PBD and Job Search Effort - Alternative Measures

\begin{tabular}{|c|c|c|c|c|c|c|}
\hline & \multicolumn{4}{|c|}{ Application index } & \multirow{2}{*}{\multicolumn{2}{|c|}{$\frac{\text { Applications per week }}{\text { OLS }}$}} \\
\hline & \multicolumn{2}{|c|}{ OLS } & \multicolumn{2}{|c|}{ Ordered Probit } & & \\
\hline & (1) & $(2)$ & $(3)$ & (4) & $(5)$ & $(6)$ \\
\hline \multirow[t]{2}{*}{ Post reform } & $0.406^{* *}$ & $0.551^{* * *}$ & $0.293^{* *}$ & $0.458^{* * *}$ & 0.516 & -0.140 \\
\hline & $(0.159)$ & $(0.190)$ & $(0.116)$ & $(0.150)$ & $(0.383)$ & $(0.416)$ \\
\hline \multirow[t]{2}{*}{ Aged 50-54 } & $0.688^{* * *}$ & $0.926^{* * *}$ & $0.455^{* * *}$ & $0.750^{* * *}$ & $1.782^{* *}$ & $1.922^{*}$ \\
\hline & $(0.226)$ & $(0.287)$ & $(0.167)$ & $(0.225)$ & $(0.906)$ & $(1.047)$ \\
\hline \multirow[t]{2}{*}{ Treatment Effect } & $-0.721^{* * *}$ & $-0.856^{* * *}$ & $-0.479^{* * *}$ & $-0.672^{* * *}$ & $-1.799^{*}$ & $-1.838^{*}$ \\
\hline & $(0.252)$ & $(0.249)$ & $(0.185)$ & $(0.197)$ & $(0.938)$ & $(0.964)$ \\
\hline Adjusted $R^{2}$ & 0.008 & 0.139 & & & 0.009 & 0.161 \\
\hline Controls & No & Yes & No & Yes & No & Yes \\
\hline Number of observations & 862 & 786 & 862 & 786 & 862 & 786 \\
\hline
\end{tabular}

Notes: This table provides regression results of the difference-in-differences model laid out in equation (1). Standard errors (in parentheses) are heteroscedasticity robust. The usual significance levels apply: ${ }^{*} p<0.1,{ }^{* *} p<0.05,{ }^{* * *} p<0.01$.

Table A.6: PBD and Job Search - Grouped Error Terms

\begin{tabular}{|c|c|c|c|c|c|c|}
\hline & \multicolumn{2}{|c|}{ Job applications } & \multicolumn{2}{|c|}{ Distant applications } & \multicolumn{2}{|c|}{ Reservation wage } \\
\hline & (1) & $(2)$ & $(3)$ & (4) & $(5)$ & (6) \\
\hline \multirow[t]{2}{*}{ Post reform } & $3.114^{*}$ & $3.720^{*}$ & 0.033 & 0.058 & -0.000 & -0.030 \\
\hline & $(1.762)$ & $(2.094)$ & $(0.037)$ & $(0.044)$ & $(0.069)$ & $(0.048)$ \\
\hline \multirow[t]{2}{*}{ Aged 50-54 } & $7.566^{* * *}$ & $9.520^{* *}$ & 0.070 & $0.150^{*}$ & -0.007 & 0.026 \\
\hline & $(2.815)$ & $(3.916)$ & $(0.053)$ & $(0.079)$ & $(0.093)$ & $(0.065)$ \\
\hline \multirow[t]{4}{*}{ Treatment Effect } & $-8.528^{* * *}$ & $-9.331^{* * *}$ & -0.067 & $-0.112^{*}$ & 0.038 & -0.013 \\
\hline & $(3.032)$ & $(3.218)$ & $(0.060)$ & $(0.063)$ & $(0.102)$ & $(0.062)$ \\
\hline & {$[3.221]$} & {$[3.390]$} & {$[0.062]$} & {$[0.065]$} & {$[0.102]$} & {$[0.062]$} \\
\hline & $\{2.958\}$ & $\{3.212\}$ & $\{0.068\}$ & $\{0.065\}$ & $\{0.100\}$ & $\{0.064\}$ \\
\hline Adjusted- $R^{2}$ & 0.010 & 0.102 & -0.001 & 0.153 & -0.003 & 0.644 \\
\hline Controls & No & Yes & No & Yes & No & Yes \\
\hline Number of observations & 862 & 786 & 862 & 786 & 687 & 634 \\
\hline
\end{tabular}

Notes: This table provides regression results of the difference-in-differences model laid out in equation (1). Standard errors in round brackets are heteroscedasticity robust, errors in squared brackets are clustered at the employment agency level. Standard errors in curly brackets are clustered at the month $\times$ federal state level. The usual significance levels apply: * $p<0.1,{ }^{* *} p<0.05,{ }^{* * *} p<0.01$. 
Table A.7: PBD and Job Search - Accounting for Selective Layoffs

\begin{tabular}{|c|c|c|c|c|c|c|}
\hline & \multicolumn{2}{|c|}{ Job applications } & \multicolumn{2}{|c|}{ Distant applications } & \multicolumn{2}{|c|}{ Reservation wage } \\
\hline & (1) & $(2)$ & (3) & (4) & $(5)$ & (6) \\
\hline \multirow[t]{2}{*}{ Post reform } & $4.998^{* * *}$ & $10.822^{* *}$ & 0.075 & $0.216^{* *}$ & 0.047 & -0.031 \\
\hline & $(1.779)$ & $(4.294)$ & $(0.056)$ & $(0.103)$ & $(0.109)$ & $(0.142)$ \\
\hline \multirow[t]{2}{*}{ Aged 50-54 } & $6.586^{* *}$ & $9.888^{* *}$ & 0.058 & 0.220 & 0.014 & -0.050 \\
\hline & $(2.827)$ & $(4.761)$ & $(0.074)$ & $(0.135)$ & $(0.145)$ & $(0.139)$ \\
\hline \multirow[t]{2}{*}{ Treatment Effect } & $-8.277^{* *}$ & $-13.077^{* * *}$ & -0.115 & -0.178 & 0.077 & 0.043 \\
\hline & $(3.359)$ & $(4.473)$ & $(0.086)$ & $(0.111)$ & $(0.162)$ & $(0.136)$ \\
\hline Adjusted- $R^{2}$ & 0.009 & 0.110 & -0.002 & 0.174 & -0.001 & 0.551 \\
\hline Controls & No & Yes & No & Yes & No & Yes \\
\hline Number of observations & 296 & 260 & 296 & 260 & 232 & 206 \\
\hline
\end{tabular}

Notes: This table provides regression results of the difference-in-differences model laid out in equation (1) when limiting the scope of strategic firm behavior. Standard errors (in parentheses) are heteroscedasticity robust. The usual significance levels apply: ${ }^{*} p<0.1,{ }^{* *}$ $p<0.05,{ }^{* * *} p<0.01$.

Table A.8: PBD and Job Search - Pseudo Treatment Effects

\begin{tabular}{|c|c|c|c|c|c|c|}
\hline & \multicolumn{2}{|c|}{ Job applications } & \multicolumn{2}{|c|}{ Distant applications } & \multicolumn{2}{|c|}{ Reservation wage } \\
\hline & (1) & (2) & (3) & (4) & (5) & (6) \\
\hline \multirow[t]{2}{*}{ Post reform } & 1.388 & 2.205 & 0.034 & 0.054 & -0.003 & -0.017 \\
\hline & $(1.390)$ & $(1.938)$ & $(0.040)$ & $(0.049)$ & $(0.062)$ & $(0.054)$ \\
\hline \multirow[t]{2}{*}{ Aged 50-54 } & -1.299 & -0.758 & -0.025 & -0.023 & 0.001 & -0.031 \\
\hline & $(1.953)$ & $(2.618)$ & $(0.048)$ & $(0.063)$ & $(0.085)$ & $(0.064)$ \\
\hline \multirow[t]{2}{*}{ Pseudo Treatment } & 1.726 & 1.279 & -0.001 & -0.003 & 0.003 & -0.019 \\
\hline & $(2.244)$ & $(2.446)$ & $(0.055)$ & $(0.057)$ & $(0.093)$ & $(0.063)$ \\
\hline Adjusted- $R^{2}$ & 0.001 & 0.114 & -0.000 & 0.115 & -0.004 & 0.619 \\
\hline Controls & No & Yes & No & Yes & No & Yes \\
\hline Number of observations & 977 & 877 & 977 & 877 & 753 & 690 \\
\hline
\end{tabular}

Notes: This table provides regression results of the difference-in-differences model laid out in equation (11) when focusing on two groups of workers that were unaffected by the reform. Standard errors (in parentheses) are heteroscedasticity robust. The usual significance levels apply: ${ }^{*} p<0.1,{ }^{* *} p<0.05,{ }^{* * *} p<0.01$. 
Table A.9: Heterogenous Effects - PBD and the Number of Applications

\begin{tabular}{|c|c|c|c|c|c|c|}
\hline Dep. Var.: Job applications & (1) & $(2)$ & $(3)$ & (4) & $(5)$ & (6) \\
\hline Post reform & $\begin{array}{c}3.064^{*} \\
(1.769)\end{array}$ & $\begin{array}{c}3.770^{*} \\
(2.100)\end{array}$ & $\begin{array}{c}3.191^{*} \\
(1.756)\end{array}$ & $\begin{array}{c}3.717^{*} \\
(2.093)\end{array}$ & $\begin{array}{c}3.202^{*} \\
(1.824)\end{array}$ & $\begin{array}{c}3.693^{*} \\
(2.096)\end{array}$ \\
\hline Aged 50-54 & $\begin{array}{c}7.564^{* * *} \\
(2.820)\end{array}$ & $\begin{array}{c}9.708^{* *} \\
(3.926)\end{array}$ & $\begin{array}{l}7.573^{* * *} \\
(2.816)\end{array}$ & $\begin{array}{c}9.533^{* *} \\
(3.949)\end{array}$ & $\begin{array}{l}7.497^{* * *} \\
(2.834)\end{array}$ & $\begin{array}{c}9.530^{* *} \\
(3.928)\end{array}$ \\
\hline Treatment $\times($ Female $)$ & $\begin{array}{l}-9.770^{* * *} \\
(3.077)\end{array}$ & $\begin{array}{l}-10.220^{* * *} \\
(3.317)\end{array}$ & & & & \\
\hline Treatment×(Male) & $\begin{array}{l}-6.821^{* *} \\
(3.412)\end{array}$ & $\begin{array}{l}-8.278^{* *} \\
(3.537)\end{array}$ & & & & \\
\hline Treatment $\times$ (Not unemployed before) & & & $\begin{array}{l}-9.120^{* * *} \\
(3.107)\end{array}$ & $\begin{array}{l}-9.234^{* * *} \\
(3.194)\end{array}$ & & \\
\hline Treatment $\times($ Unemployed before $)$ & & & $\begin{array}{l}-8.297^{* *} \\
(3.254)\end{array}$ & $\begin{array}{l}-9.390^{* * *} \\
(3.498)\end{array}$ & & \\
\hline Treatment $\times($ Low-Skilled $)$ & & & & & $\begin{array}{l}-8.385^{* *} \\
(3.869)\end{array}$ & $\begin{array}{l}-9.705^{* *} \\
(4.345)\end{array}$ \\
\hline Treatment×(Medium-Skilled) & & & & & $\begin{array}{l}-9.176^{* * *} \\
(3.206)\end{array}$ & $\begin{array}{l}-9.579^{* * *} \\
(3.439)\end{array}$ \\
\hline Treatment $\times($ High-Skilled $)$ & & & & & $\begin{array}{l}-7.201^{* *} \\
(3.465)\end{array}$ & $\begin{array}{l}-8.762^{* *} \\
(3.544)\end{array}$ \\
\hline Adjusted- $R^{2}$ & 0.013 & 0.101 & 0.008 & 0.100 & 0.012 & 0.099 \\
\hline Controls & No & Yes & No & Yes & No & Yes \\
\hline Number of observations & 862 & 786 & 861 & 786 & 853 & 786 \\
\hline
\end{tabular}

Notes: This table provides regression results of the difference-in-differences model laid out in equation (1), allowing for heterogeneous treatment effects by (a) gender, (b) previous unemployment experience, and (c) the level of training. The dependent variable is the number of filed applications. Standard errors (in parentheses) are heteroscedasticity robust. The usual significance levels apply: * $p<0.1,{ }^{* *} p<0.05,{ }^{* * *} p<0.01$. 
Table A.10: Heterogenous Effects - PBD and Applying for Jobs in Distant Areas

\begin{tabular}{|c|c|c|c|c|c|c|}
\hline Dep. Var.: Distant Applications & (1) & $(2)$ & $(3)$ & $(4)$ & $(5)$ & $(6)$ \\
\hline Post reform & $\begin{array}{r}0.028 \\
(0.037)\end{array}$ & $\begin{array}{r}0.057 \\
(0.044)\end{array}$ & $\begin{array}{r}0.039 \\
(0.036)\end{array}$ & $\begin{array}{r}0.057 \\
(0.044)\end{array}$ & $\begin{array}{r}0.047 \\
(0.038)\end{array}$ & $\begin{array}{r}0.054 \\
(0.044)\end{array}$ \\
\hline Aged 50-54 & $\begin{array}{r}0.070 \\
(0.053)\end{array}$ & $\begin{array}{c}0.146^{*} \\
0.079)\end{array}$ & $\begin{array}{r}0.070 \\
(0.053)\end{array}$ & $\begin{array}{c}0.153^{*} \\
(0.079)\end{array}$ & $\begin{array}{r}0.079 \\
(0.053)\end{array}$ & $\begin{array}{c}0.149^{*} \\
(0.078)\end{array}$ \\
\hline Treatment $\times($ Female $)$ & $\begin{array}{r}-0.077 \\
(0.060)\end{array}$ & $\begin{array}{l}-0.094 \\
(0.067)\end{array}$ & & & & \\
\hline Treatment×(Male) & $\begin{array}{r}-0.049 \\
(0.071)\end{array}$ & $\begin{array}{l}-0.132^{*} \\
(0.069)\end{array}$ & & & & \\
\hline Treatment $\times($ Not unemployed before $)$ & & & $\begin{array}{r}-0.077 \\
(0.068)\end{array}$ & $\begin{array}{r}-0.087 \\
(0.069)\end{array}$ & & \\
\hline Treatment $\times($ Unemployed before $)$ & & & $\begin{array}{r}-0.067 \\
(0.063)\end{array}$ & $\begin{array}{c}-0.126^{*} \\
(0.068)\end{array}$ & & \\
\hline Treatment $\times($ Low-Skilled $)$ & & & & & $\begin{array}{l}-0.192^{* * *} \\
(0.072)\end{array}$ & $\begin{array}{c}-0.250^{* *} \\
(0.103)\end{array}$ \\
\hline Treatment×(Medium-Skilled) & & & & & $\begin{array}{r}-0.097 \\
(0.061)\end{array}$ & $\begin{array}{c}-0.118^{*} \\
(0.065)\end{array}$ \\
\hline Treatment $\times($ High-Skilled $)$ & & & & & $\begin{array}{r}-0.026 \\
(0.077)\end{array}$ & $\begin{array}{r}-0.069 \\
(0.076)\end{array}$ \\
\hline Adjusted- $R^{2}$ & 0.020 & 0.152 & 0.003 & 0.152 & 0.045 & 0.154 \\
\hline Controls & No & Yes & No & Yes & No & Yes \\
\hline Number of observations & 862 & 786 & 861 & 786 & 853 & 786 \\
\hline
\end{tabular}

Notes: This table provides regression results of the difference-in-differences model laid out in equation (1), allowing for heterogeneous treatment effects by (a) gender, (b) previous unemployment experience, and (c) the level of training. The dependent variable is the probability of applying for jobs in distant areas. Standard errors (in parentheses) are heteroscedasticity robust. The usual significance levels apply: ${ }^{*} p<0.1,{ }^{* *} p<0.05$, ${ }^{* * *} p<0.01$. 